SUMMARY OF DATA COLLECTED FOR THE DEMONSTRATION EROSION CONTROL PROJECT IN THE YAZOO RIVER BASIN, NORTH-CENTRAL MISSISSIPPI, OCTOBER 1996 - SEPTEMBER 1997

By Michael S. Runner and B. Allen Roberts

U.S. GEOLOGICAL SURVEY

Open-File Report 99-61

Prepared in cooperation with the U.S. ARMY CORPS OF ENGINEERS, Vicksburg District

Pearl, Mississippi 1999

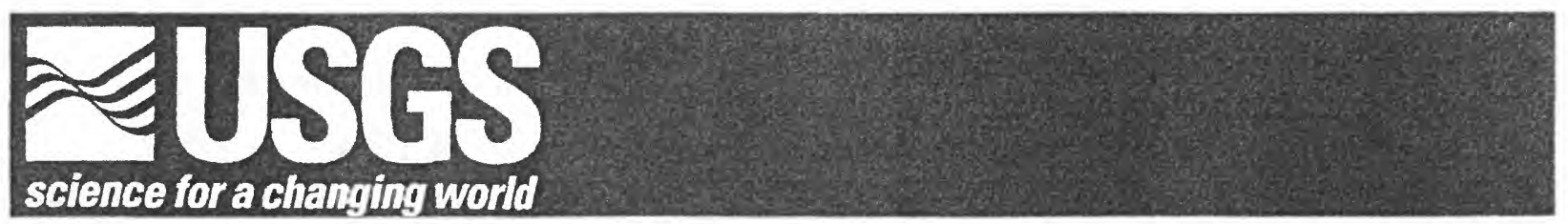




\section{U.S. DEPARTMENT OF THE INTERIOR \\ BRUCE BABBITT, Secretary \\ U.S. GEOLOGICAL SURVEY \\ Charles G. Groat, Director}

For additional information write to:

District Chief

U.S. Geological Survey 308 South Airport Road

Pearl, MS 39208-6649
Copies of this report can be purchased from:

U.S. Geological Survey

Branch of Information Services Box 25286

Denver, CO 80225-0286 


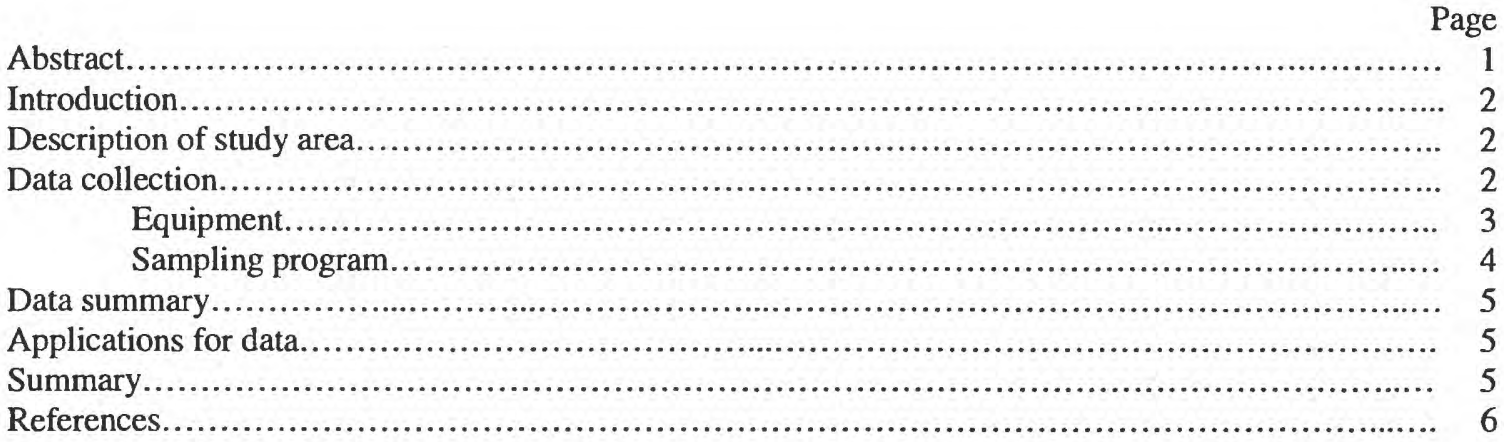

\section{ILLUSTRATIONS}

Figure 1. Yazoo River Basin and Demonstration Erosion Control Project study basins and datacollection stations, 1997 water year.

2 - 8. Graphs showing grain-size analyses for samples collected in July 1997

2. Hotopha Creek near Batesville.

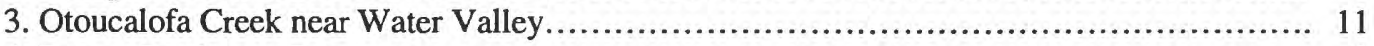

4. Peters Creek near Pope................................................................ 12

5. Hickahala Creek near Senatobia...................................................... 12

6. Abiaca Creek near Seven Pines............................................................. 13

7. Abiaca Creek near Cruger.................................................................... 13

8. Harland Creek near Howard.............................................................. 14

9 - 16. Graphs showing values for the 1997 water year and median values for the period of record for (a) monthly-mean stream discharge, (b) monthly-mean suspended-sediment concentration, and (c) suspended-sediment discharge for

9. Hotopha Creek near Batesville..................................................... 15

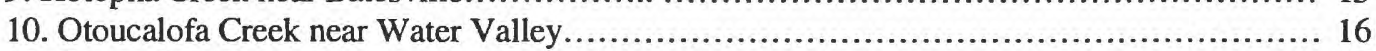

11. Peters Creek near Pope................................................................. 17

12. Hickahala Creek near Senatobia........................................................... 18

13. Batupan Bogue at Grenada........................................................... 19

14. Abiaca Creek near Seven Pines........................................................... 20

15. Abiaca Creek near Cruger................................................................. 21

16. Harland Creek near Howard ............................................................ 22

17 - 18. Graphs showing values for the 1997 water year for (a) monthly-mean stream discharge,

(b) monthly-mean suspended-sediment concentration, and (c) suspended-sediment discharge for

17. Yalobusha River near Calhoun City .................................................... 23

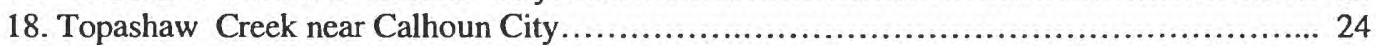

\section{TABLES}

Table 1. Data-collection sites for the Demonstration Erosion Control Project, 1985-97................ 7

2. Summary of data collected for the Demonstration Erosion Control Project, October 1996 - September 1997.

3. Maximum and minimum instantaneous values for the Demonstration Erosion Control Project, October 1996 - September 1997

4. Maximum and minimum daily-mean values for the Demonstration Erosion Control Project, October 1996 - September 1997

5. Total-sediment discharge for the 1997 water year, and extremes for the period of record for Demonstration Erosion Control Project 1997 sediment-data-collection stations. 


\section{CONVERSION FACTORS}

For use of readers who prefer to use units other than those used in this report, the following conversion factors may be used:

\begin{tabular}{rcl}
\hline Multiply & By & To obtain \\
inch (in.) & 25.4 & millimeter $(\mathrm{mm})$ \\
square mile $\left(\mathrm{mi}^{2}\right)$ & 2.59 & square kilometer $\left(\mathrm{km}^{2}\right)$ \\
square mile $\left(\mathrm{mi}^{2}\right)$ & 640 & acre \\
cubic foot $\left(\mathrm{ft}^{3}\right)$ & 0.02832 & cubic meter $\left(\mathrm{m}^{3}\right)$ \\
cubic foot per second $\left(\mathrm{ft}^{3} / \mathrm{s}\right)$ & 0.02832 & cubic meter per second $\left(\mathrm{m}^{3} / \mathrm{s}\right)$ \\
pound $(\mathrm{lb})$ mass & 453.6 & gram $(\mathrm{mg})$ \\
pound per gallon (lb/gal) & 119,800 & milligram per liter $(\mathrm{mg} / \mathrm{L})$ \\
gallon $(\mathrm{gal})$ & 3.785 & liter $(\mathrm{L})$ \\
\hline
\end{tabular}




\title{
SUMMARY OF DATA COLLECTED FOR THE DEMONSTRATION EROSION CONTROL PROJECT IN THE YAZOO RIVER BASIN, NORTH-CENTRAL MISSISSIPPI, OCTOBER 1996 - SEPTEMBER 1997
}

\author{
Michael S. Runner and B. Allen Roberts
}

\begin{abstract}
During the 1997 water year, U.S. Geological Survey personnel collected data at 14 stations as part of the U.S. Army Corps of Engineers Demonstration Erosion Control Project in north-central Mississippi. The stations were equipped with electronic datacollection platforms that recorded and transmitted stage, precipitation (where applicable), sample count from automatic samplers (where applicable), and instrument battery voltage. Data collected or computed included continuous stage and discharge at all 14 stations, continuous suspended-sediment concentrations and loads at 10 of the 14 stations, and discrete water-quality samples at 2 of the 10 sediment stations. Approximately 6,500 suspended-sediment samples, 7 bed-material samples, and 34 water-quality samples were collected; and 170 stream-discharge measurements were made.
\end{abstract}




\section{INTRODUCTION}

In 1984, Congress directed the U.S. Army Corps of Engineers (COE) and the U.S. Department of Agriculture Soil Conservation Service, now the Natural Resources Conservation Service (NRCS), to establish demonstration watersheds for the purpose of studying erosion and sedimentation in agricultural watersheds. One of the selected studies, the Demonstration Erosion Control (DEC) Project, is located in the upper Yazoo River Basin in north-central Mississippi (fig. 1). The project is an ongoing, multi-agency effort for the planning, construction, and evaluation of projects to alleviate erosion, sedimentation, and flooding problems in the Bluff Hills that border the Mississippi River alluvial plain.

In 1985, the U.S. Geological Survey (USGS) started collecting sediment and water-quality data for the Yazoo River Basin DEC Project at the request of the Interagency Task Force on the Yazoo Basin Foothills Erosion and Flood Control. Since inception of the project, the type of data collected, the collection methods, and the number and location of the data-collection sites have changed in accordance with the needs and requests of the cooperating agencies (Runner and Roberts, 1998). These data are collected to monitor the effects of remediation and stabilization projects in the upper Yazoo River Basin. Data have been published annually since 1989 by the USGS in the report, "Water Resources Data for Mississippi" The data are also available in the USGS Water Data Storage and Retrieval System (WATSTORE).

The purpose of this report is to summarize the data collected by the USGS for the DEC Project during the period October 1996 through September 1997.

\section{DESCRIPTION OF STUDY AREA}

The DEC Project study area is located in the upper Yazoo River Basin in northcentral Mississippi (fig. 1). This area consists primarily of agricultural and forested lands. Problems associated with flooding, stream erosion, and soil loss from agricultural lands are common. Extensive channel-restoration projects, flood-control ponds, and field-level sediment- and discharge-control structures are present in the study area.

\section{DATA COLLECTION}

Water-level recorders were operated at all 14 continuous-record stations in the DEC Project to provide a continuous record of river stage. Discharge measurements were made by USGS personnel during routine field trips and during storm events in order to establish and maintain a current stage-discharge relation at each station. Sediment samples were collected by USGS personnel, by gage observers (local residents under contract with the USGS), and by PS-69 automatic samplers. These data were used to establish the relation between discharge and suspended-sediment concentration. Waterquality samples and data were collected by USGS personnel during scheduled field trips. Currently, the USGS operates 14 continuous-record stations and 15 partial-record stations in eight drainage basins in the DEC Project study area (table 1). The total drainage area upstream of the USGS sampling sites is 1,350 square miles. Of this area, 1,050 square miles is upstream of continuous-sediment stations. 


\section{Equipment}

For the computation of continuous discharge and sediment records, it was necessary to collect accurate continuous-stage data. Stage-measuring equipment for the 14 stations consisted of 12 nitrogen-bubbler systems and 2 stilling wells. At each of the stations except one, the primary stage recorder was an electronic data-collection platform (DCP). The exception was the Yalobusha River near Calhoun City station which had an analog punched-tape data recorder as the primary stage recorder with a DCP serving as a backup. In addition to the stage data, the DCP's recorded rainfall data, instrument battery voltage, and sample count. The stage-recording equipment was housed in fiberglass or aluminum shelters located on the stream bank where possible, or on the downstream side of a bridge. Data recorders were powered by 12 -volt batteries recharged by solar panels. The recorded data were transmitted via satellite to the USGS District office (Pearl, Mississippi) and stored in the District computer system.

Discharge measurements were made using standard USGS Price AA or Pygmy current meters. Discharge measurements were made either by wading the stream or by suspending the meter with a weight on a cable from a bridge. Due to the unsafe condition of the bridge at Harland Creek near Howard, a bank-operated cableway was installed to facilitate high-flow data collection. The collection, computation, and analysis of stage and discharge data were done in accordance to U.S. Geological Survey technical publications (Rantz and others, 1982a,b).

Suspended-sediment samples were collected either manually or by automatic samplers. The equipment used for manual sediment sampling was obtained through the Federal Interagency Sedimentation Project (FISP) in Vicksburg, Miss. Depending upon stream conditions, one of several depth-integrated sediment samplers was used to collect suspended-sediment samples (Guy and Norman, 1970). Low-flow conditions generally allowed for wading of the stream for measurement and sampling purposes. Samples were collected using a DH-48 depth-integrating, suspended-sediment sampler attached to a hand-held rod. When stream-flow conditions prohibited the wading of a stream, a DH-59 suspended-sediment sampler on a rope, lowered by hand from a bridge, or a D-74 sampler on a truck-mounted power rig was used. For depths greater than 15 feet a P-61 point sampler was used. At Harland Creek near Howard, a bank-operated cableway system and a D-74 sampler were used to collect samples when wading was not possible. Station observers collected samples by using a DH-48 hand sampler, a DH-59 rope sampler, or a D-74 sampler mounted to the bridge.

Suspended-sediment samples were also collected by PS-69 automatic samplers. The PS-69 was designed and distributed by the FISP. These samplers were activated by DCP's when the water level exceeded a predetermined threshold. The sampling frequency was controlled by the DCP's and was dependent on the rate-of-change of the stage.

Bed-material samples were collected using one of three samplers supplied by the FISP. At low water, when wading was possible, a BMH-53 piston-type bed-material sampler was used. When the water was too deep to wade, either a BMH-60 hand-line sampler on a rope, or a BM-54 bed-material sampler on a truck-mounted power rig was used.

Water-quality samples for laboratory analysis were collected by USGS personnel according to USGS standards (Wilde and others, 1998). Field measurements of 
temperature, $\mathrm{pH}$, dissolved oxygen, and specific conductance were obtained using Hydrolab water-quality monitors.

Suspended-and bed-material sediment samples were analyzed at USGS sediment laboratories located in Baton Rouge, La., Tuscaloosa, Ala., or Rolla, Mo. Water-quality samples were analyzed at USGS laboratories in Denver, Colo., and Ocala, Fla.

\section{$\underline{\text { Sampling Program }}$}

Sediment sampling for DEC during the 1997 water year was done at 10 continuous sediment-stations in eight drainage basins. At each station, samples were collected by USGS personnel, station observers, and automatic samplers.

USGS personnel visited each station every 3 weeks for sampling and gage maintenance, and measured flow at least once every 6 weeks. Stations affected by construction work such as bank stabilization or channelization near the gage, or by backwater from lakes or other streams, were measured more often to assist in the discharge analysis. Sites were also visited during storm events to collect samples to determine high-flow concentrations and to calibrate the automatic samplers. USGS personnel use the equal-width increment (EWI), depth-integrated sampling methods to collect samples representative of the stream cross section. Because observer's samples and the PS-69-pumped samples represent only a single vertical in the transect or a single point in the water column, they must be adjusted to represent the entire cross section. This adjustment is accomplished by concurrently sampling the stream cross section and the single vertical sampled by the observer, and then using these data to compute coefficients that are applied to the observer's sample data to make them better represent the cross section. A similar approach is used for the PS-69 data. On well-mixed streams, point and single-vertical samples are generally representative of the entire cross section and the coefficient nears 1.0 (Vanoni, 1977).

The automatic samplers were stage-activated with sampling programs dependent on hydrograph characteristics of the specific station. After the sampler was activated, samples were collected at programmed intervals while the threshold stage was exceeded. The sample interval was dependent on the rate of change of the stage. All samples collected were analyzed for total sediment concentration. Selected samples such as those collected at extreme stages and those corresponding to an EWI or single-vertical sample were analyzed for sand/silt percentages. Analysis of PS-69 samples for sand/silt concentrations help determine if intake placement for the sampler is appropriate in relation to the stream bed.

Bed-material analyses for grain size were performed on samples collected in July 1997 from seven of the continuous-sediment stations. The seven stations were selected based on the existence of historical bed-material data. At each station, samples were collected from three locations in the stream bed, one each at 25, 50 and 75 percent of the stream width from left to right looking downstream. The results of the analyses for each station appear in figures 2-8.

Water-quality samples and field data were collected every 3 weeks at two sites: Topashaw Creek near Calhoun City and Yalobusha River near Calhoun City. Field measurements were made for $\mathrm{pH}$, specific conductance, temperature, and dissolved oxygen. Water samples were analyzed for nitrogen, phosphorus, and total organic carbon. 
During the 1997 water year, the USGS made 170 stream-discharge measurements and collected more than 6,800 sediment samples. Of these sediment samples, approximately 4,500 were collected by automatic samplers, 2,000 were collected by station observers, and 329 were collected by USGS personnel. USGS personnel also collected 34 water-quality samples and seven bed-material samples (table 2).

\section{DATA SUMMARY}

The suspended-sediment concentration data were used in conjunction with the instantaneous-discharge data to compute the sediment discharge for each station. Daily mean values for discharge, suspended-sediment concentration, and suspended-sediment discharge are published in the USGS publication "Water Resources Data, Mississippi, Water Year 1997" (Plunkett, and others, 1998). The maximum recorded instantaneousstream discharge for all of the DEC stations was $21,800 \mathrm{ft}^{3} / \mathrm{s}$ at the Yalobusha River near Calhoun City. The maximum instantaneous suspended-sediment concentration measured was $15,200 \mathrm{mg} / \mathrm{L}$ at Peters Creek near Pope (table 3). The peak stream-discharge at Black Creek at Lexington of $18,600 \mathrm{ft}^{3} / \mathrm{s}$ on June 10 was between a 10 - and 25 -year flood. The maximum daily-mean suspended-sediment concentration was $3,360 \mathrm{mg} / \mathrm{L}$ at Harland Creek near Howard. The maximum daily-mean suspended-sediment discharge was $98,100 \mathrm{t} / \mathrm{d}$ at Batupan Bogue at Grenada (table 4). The maximum annual suspendedsediment discharge was 860,000 tons per year at Batupan Bogue at Grenada, Mississippi. The minimum annual suspended-sediment discharge was 42,200 tons per year at Hotopha Creek near Batesville, Mississippi (table 5). Monthly values for daily-mean discharge, daily-mean suspended-sediment concentration, and total suspended-sediment discharge for the 1997 water year, and the median values for the same parameters for the period of record, are shown in figures 9 through 32. The values for the Yalobusha River near Calhoun City and Topashaw Creek near Calhoun City are shown for the 1997 water year only in figures 33 through 38 .

\section{APPLICATIONS FOR DATA}

The results from the USGS sediment and water-quality sampling program are stored in the USGS District database. Data will be used in conjunction with historical data to evaluate the effects of completed and ongoing remediation in the upper Yazoo River Basin. Discharge data from the DEC sites are also used in conjunction with the USGS stream-gage network to improve our understanding of flood, flow-duration, and low-flow characteristics of Mississippi streams.

\section{SUMMARY}

Since July 1985, the U.S. Geological Survey has sampled sediment and waterquality at sites in the upper Yazoo River Basin. During the 1997 water year, data were collected at 10 sediment-collection sites ( 2 of which were water-quality sites), 4 continuous-stage sites, and 15 partial-record sites. Sediment samples were collected manually by USGS personnel and station observers and automatically by PS-69 samplers.

One hundred seventy stream-discharge measurements were made to develop and maintain stage-discharge ratings for the stations and to compute the sediment loading 
rates. More than 6,800 sediment samples were collected during the 1997 water year. Thirty-four water-quality samples and field-parameter measurements were collected at the DEC sites. Bed-material samples were collected at selected sediment stations and were analyzed for particle-size distribution. Results from the analysis of the sediment and water-quality samples are used to monitor the effects of sediment, erosion, and floodcontrol measures implemented in the region. A yearly compilation of the sediment, discharge, and water-quality data collected on all the DEC sites was published by the USGS in the report "Water Resources Data, Mississippi, Water Year 1997."

\section{REFERENCES}

Guy, H.P., and Norman, V.W., 1970, Field methods for measurement of fluvial sediment: U.S. Geological Survey Techniques of Water-Resources Investigations, book 3, chapter $\mathrm{C} 2,59 \mathrm{p}$.

Plunkett, M.L., Morris, F.M. III, Oakley, W.T., and Turnipseed, D.P., 1998, Water resources data, Mississippi, water year 1997: U.S. Geological Survey water-data report MS-97-1, $308 \mathrm{p}$.

Rantz, S.E., and others, 1982a, Measurement and computation of streamflow: Volume 1. Measurement of stage and discharge: U.S. Geological Survey Water-Supply Paper $2175,284 \mathrm{p}$.

---- 1982b, Measurement and computation of streamflow: Volume 2. Computation of discharge: U.S. Geological Survey Water-Supply Paper 2175, p 285 - 631.

Runner, M.S., and Roberts, B.A., 1998, Data-collection methods used in the Demonstration Erosion Control project in the Yazoo River Basin, north-central Mississippi, July 1985 - September 1997: U.S. Geological Survey Open-File Report 98-560, 9p.

Wilde, F.D., and others, 1998, National field manual for the collection of water-quality data: U.S. Geological Survey Techniques of Water-Resources Investigations; book 9, variously paginated.

Vanoni, V.A., 1977, Sediment engineering: ASCE-Manuals and Reports on Engineering Practice- no. 54. 
Table 1. Data-collection sites for the Demonstration Erosion Control Project, 1985-97

[D.A., drainage area; $\mathrm{mi}^{2}$, square miles]

\begin{tabular}{|c|c|c|c|c|c|}
\hline Drainage basin & $\begin{array}{l}\text { Data-collection site } \\
\text { (map ID no. on fig. 1) }\end{array}$ & $\begin{array}{l}\text { D.A. } \\
\mathrm{mi}^{2}\end{array}$ & Period of Record & Equipment & Data collected \\
\hline Hickahala Creek & Hickahala Cr. nr Independence (1) & 25.3 & Feb. 1988 - present & None & Storm data \\
\hline Hickahala Creek & Hickahala Cr. nr Looxahoma (2) & 44.6 & Feb. 1988 - present & None & Storm data \\
\hline Hickahala Creek & James Wolf Cr. nr Looxahoma (3) & 35.2 & Feb. 1988 - present & None & Storm data \\
\hline Hickahala Creek & Hickahala Cr. nr Senatobia (4) & 121 & Jan. 1986 - present & Stage, sediment & Continuous data \\
\hline Hickahala Creek & Senatobia Cr. nr Como (5) & 20.4 & Feb. 1988 - present & None & Storm data \\
\hline Hickahala Creek & Senatobia Cr. nr Senatobia (6) & 82.0 & Feb. 1986 - present & Stage only & Continuous data \\
\hline Otoucalofa Creek & Otoucalofa Cr. nr Paris (7) & 8.28 & Feb. 1988 - present & None & Storm data \\
\hline Otoucalofa Creek & Otoucalofa Cr. at Paris (8) & 21.0 & Feb. 1988 - present & None & Storm data \\
\hline Otoucalofa Creek & $\begin{array}{l}\text { Otoucalofa Cr. E. of } \\
\text { Water Valley (9) }\end{array}$ & 46.5 & Feb. 1988 - present & None & Storm data \\
\hline Otoucalofa Creek & $\begin{array}{l}\text { Otoucalofa Cr. E-SE of } \\
\text { Water Valley (10) }\end{array}$ & 74.0 & Feb. 1988 - present & None & Storm data \\
\hline Otoucalofa Creek & Town Cr. at Water Valley (11) & 2.25 & Dec. 1984 - present & Stage only & Continuous data \\
\hline Otoucalofa Creek & $\begin{array}{l}\text { Otoucalofa Cr. nr. } \\
\text { Water Valley (12) }\end{array}$ & 97.1 & June 1985 - present & Stage, sediment & Continuous data \\
\hline Black Creek & Fannegusha Cr. nr Ituma (13) & 39.8 & Feb. 1988 - present & None & Storm data \\
\hline Black Creek & Fannegusha $\mathrm{Cr}$. nr Howard (14) & 107 & Mar. 1987 - present & Stage only & Continuous data \\
\hline Black Creek & Black Cr. at Bowling Green (15) & 28.2 & Feb. 1988 - present & None & Storm data \\
\hline Black Creek & Black Cr. at Lexington (16) & 88.1 & Feb 1987 - present & Stage only & Continuous data \\
\hline Black Creek & Harland Cr. nr Howard (17) & 62.1 & Nov. 1986 - present & Stage, sediment & Continuous data \\
\hline Black Creek & Black Cr. at Howard (18) & 5.64 & Feb 1988 - present & None & Storm data \\
\hline Abiaca Creek & Abiaca Cr. nr Coila (19) & & Oct. 1991 - present & None & Storm data \\
\hline Abiaca Creek & Abiaca Cr. nr Black Hawk (20) & 10.7 & Oct. 1991 - present & None & Storm data \\
\hline Abiaca Creek & Abiaca Cr. at Black Hawk (21) & 28.3 & Oct. 1991 - present & None & Storm data \\
\hline Abiaca Creek & Coila Cr. at Seven Pines (22) & 39.8 & Oct. 1991 - present & None & Storm data \\
\hline Abiaca Creek & Abiaca Cr. nr Seven Pines (23) & 97.2 & Oct. 1991 - present & Stage, sediment & Continuous data \\
\hline Abiaca Creek & Abiaca Cr. at Cruger (24) & 97.7 & Oct. 1991 - present & Stage, sediment & Continuous data \\
\hline Hotopha Creek & Hotopha Cr. nr Batesville (25) & 35.1 & March 1986 - present & Stage, sediment & Continuous data \\
\hline Peters Creek & Peters (Long) Cr. nr Pope (26) & 79.2 & Dec. 1986 - present & Stage, sediment & Continuous data \\
\hline Batupan Bogue & Batupan Bogue at Grenada (27) & 254 & June 1985 - present & Stage, sediment & Continuous data \\
\hline Yalobusha River & Yalobusha R. nr Calhoun City (28) & 305 & Oct 1996 - present & Stage, sediment & Continuous data \\
\hline Yalobusha River & Topashaw Cr. nr Calhoun City (29) & * & Oct 1996 - present & Stage, sediment & Continuous data \\
\hline
\end{tabular}

*Drainage area combined with Yalobusha River for data compilation and statistical analyses. 
Table 2.-Summary of data collected for the Demonstration Erosion Control Project, October 1996-

September 1997

\begin{tabular}{lcccc}
\hline \multicolumn{1}{c}{ Station } & $\begin{array}{c}\text { Number of } \\
\text { discharge } \\
\text { measurements }\end{array}$ & $\begin{array}{c}\text { Suspended } \\
\text { sediment }\end{array}$ & $\begin{array}{c}\text { Total number of samples } \\
\text { Bed } \\
\text { material }\end{array}$ & $\begin{array}{c}\text { Water- } \\
\text { quality }\end{array}$ \\
\hline Hotopha Creek near Batesville & 13 & 889 & 1 & 0 \\
Otoucalofa Creek near Water Valley & 19 & 787 & 1 & 0 \\
Peters (Long) Creek near Pope & 11 & 525 & 1 & 0 \\
Hickahala Creek near Senatobia & 12 & 603 & 0 & 0 \\
Batupan Bogue at Grenada & 17 & 1,189 & 1 & 0 \\
Abiaca Creek near Seven Pines & 13 & 472 & 1 & 0 \\
Abiaca Creek near Cruger & 17 & 459 & 1 & 0 \\
Harland Creek near Howard & 10 & 668 & 0 & 17 \\
Yalobusha River near Calhoun City & 5 & 542 & 0 & 17 \\
Topashaw Creek near Calhoun City & 6 & 682 & 0 & 0 \\
Town Creek at Water Valley & 11 & 0 & 0 & 0 \\
Senatobia Creek near Senatobia & 13 & 0 & 0 & 0 \\
Fannegusha Creek near Howard & 12 & 11 & 0 & 0
\end{tabular}

Table 3.-Maximum and minimum instantaneous values for the Demonstration Erosion Control Project, October 1996 - September 1997 (Plunkett and others, 1998)

\begin{tabular}{|c|c|c|c|c|}
\hline \multirow[t]{2}{*}{ Station } & \multicolumn{2}{|c|}{$\begin{array}{c}\text { Stream discharge } \\
\text { in cubic feet per second }\end{array}$} & \multicolumn{2}{|c|}{$\begin{array}{l}\text { Suspended-sediment concentration } \\
\text { in milligrams per liter }\end{array}$} \\
\hline & Maximum & Minimum & Maximum & Minimum \\
\hline Hotopha Creek near Batesville & 2,670 & 7.4 & 3,847 & 11 \\
\hline Otoucalofa Creek near Water Valley & 6,720 & 26 & 10,300 & 20 \\
\hline Peters (Long) Creek near Pope & 14,300 & 9.2 & 15,231 & 10 \\
\hline Hickahala Creek near Senatobia & 10,200 & 33 & 5,526 & 15 \\
\hline Batupan Bogue at Grenada & 21,200 & 17 & 9,213 & 7 \\
\hline Abiaca Creek near Seven Pines & 5,670 & 26 & 9,287 & 34 \\
\hline Abiaca Creek near Cruger & 3,000 & 24 & 6,074 & 23 \\
\hline Harland Creek near Howard & 6,190 & 8.1 & 11,241 & 5 \\
\hline Yalobusha River near Calhoun City & 21,800 & 6.6 & 5,068 & 25 \\
\hline Topashaw Creek near Calhoun City & 9,480 & 3.2 & 8,375 & 24 \\
\hline Town Creek at Water Valley & 841 & 1.9 & 0 & 0 \\
\hline Senatobia Creek near Senatobia & 12,700 & 11 & 0 & 0 \\
\hline Fannegusha Creek near Howard & 14,400 & 16 & 0 & 0 \\
\hline Black Creek at Lexington & 18,600 & 19 & 0 & 0 \\
\hline
\end{tabular}


Table 4.-Maximum and minimum daily-mean values for the Demonstration Erosion Control Project, October 1996 - September 1997 (Plunkett and others, 1998)

\begin{tabular}{|c|c|c|c|c|}
\hline \multirow[t]{2}{*}{ Station } & \multicolumn{2}{|c|}{$\begin{array}{l}\text { Daily-mean suspended- } \\
\text { sediment concentration } \\
\text { in milligrams per liter }\end{array}$} & \multicolumn{2}{|c|}{$\begin{array}{l}\text { Daily-mean suspended- } \\
\text { sediment discharge } \\
\text { in tons per day }\end{array}$} \\
\hline & Maximum & Minimum & Maximum & Minimum \\
\hline Hotopha Creek near Batesville & 1,260 & 11 & 4,840 & 0.23 \\
\hline Otoucalofa Creek near Water Valley & 2,440 & 24 & 18,200 & 2.0 \\
\hline Peters (Long) Creek near Pope & 3,190 & 10 & 34,800 & .32 \\
\hline Hickahala Creek near Senatobia & 2,210 & 17 & 38,500 & 2.2 \\
\hline Batupan Bogue at Grenada & 2,570 & 24 & 98,100 & 1.7 \\
\hline Abiaca Creek near Seven Pines & 1,970 & 35 & 18,400 & 2.6 \\
\hline Abiaca Creek near Cruger & 2,180 & 24 & 13,300 & 2.1 \\
\hline Harland Creek near Howard & 3,360 & 21 & 41,800 & .61 \\
\hline Yalobusha River near Calhoun City & 1,530 & 25 & 38,700 & 1.0 \\
\hline Topashaw Creek near Calhoun City & 2,360 & 25 & 37,400 & .33 \\
\hline Town Creek at Water Valley & 0 & 0 & 0 & 0 \\
\hline Senatobia Creek near Senatobia & 0 & 0 & 0 & 0 \\
\hline Fannegusha Creek near Howard & 0 & 0 & 0 & 0 \\
\hline Black Creek at Lexington & 0 & 0 & 0 & 0 \\
\hline
\end{tabular}

Table 5.-Total-sediment discharge for the 1997 water year, and extremes for period of record for Demonstration Erosion Control Project 1997 sediment-data collection stations

\begin{tabular}{|c|c|c|c|c|}
\hline \multirow{2}{*}{ Station } & \multirow{2}{*}{$\begin{array}{c}1997 \text { water year } \\
\text { suspended-sediment } \\
\text { discharge, } \\
\text { in tons per year }\end{array}$} & \multicolumn{3}{|c|}{ Period of record } \\
\hline & & $\begin{array}{l}\text { maximum discharge, } \\
\text { in tons per year } \\
\text { (water year) }\end{array}$ & $\begin{array}{l}\text { minimum discharge, } \\
\text { in tons per year } \\
\text { (water year) }\end{array}$ & $\begin{array}{l}\text { median discharge, } \\
\text { in tons per year }\end{array}$ \\
\hline Hotopha Creek nr Batesville & 42,200 & $194,000(1991)$ & $14,000(1993)$ & 43,100 \\
\hline Otoucalofa Creek nr Water Valley & 220,000 & $519,000(1991)$ & $69,100(1986)$ & 216,000 \\
\hline Peters Creek nr Pope & 280,000 & $513,000(1992)$ & $65,400(1996)$ & 236,000 \\
\hline Hickahala Creek nr Senatobia & 232,000 & $655,000(1989)$ & $74,400(1996)$ & 232,000 \\
\hline Batupan Bogue at Grenada & 620,000 & $890,000(1988)$ & $95,000(1986)$ & 458,000 \\
\hline Abiaca Creek nr Seven Pines & 129,000 & $129,000(1997)$ & $56,200(1993)$ & 97,300 \\
\hline Abiaca Creek nr Cruger & 86,700 & $86,700(1997)$ & $49,800(1993)$ & 76,300 \\
\hline Harland Creek nr Howard & 216,000 & $486,000(1991)$ & $97,000(1996)$ & 201,000 \\
\hline Yalobusha River nr Calhoun City & 296,000 & ** & $* *$ & ** \\
\hline Topashaw Creek nr Calhoun City & 286,000 & $* *$ & ** & ** \\
\hline
\end{tabular}

** One year of sediment record only, no maximum, minimum, or median statistics available 


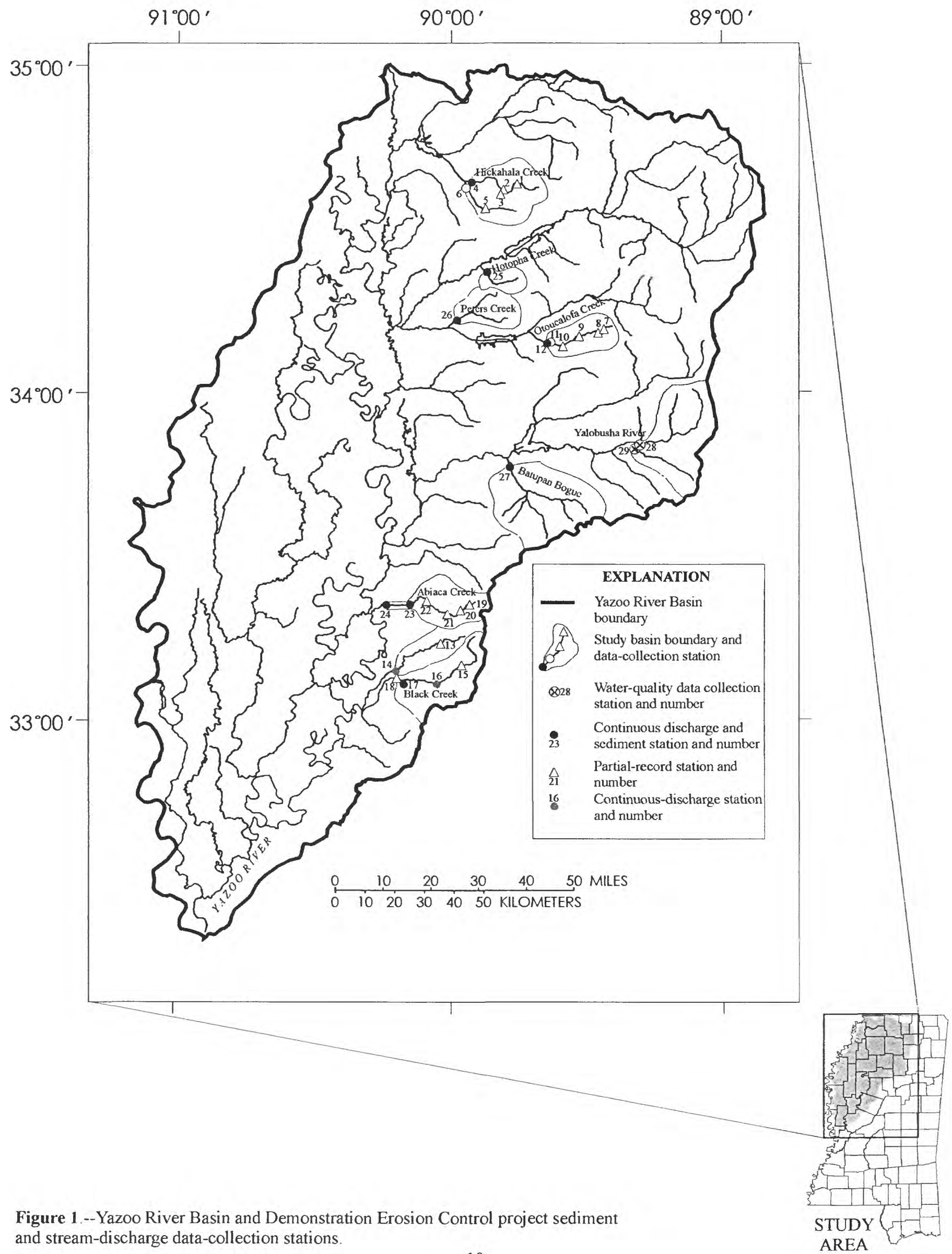




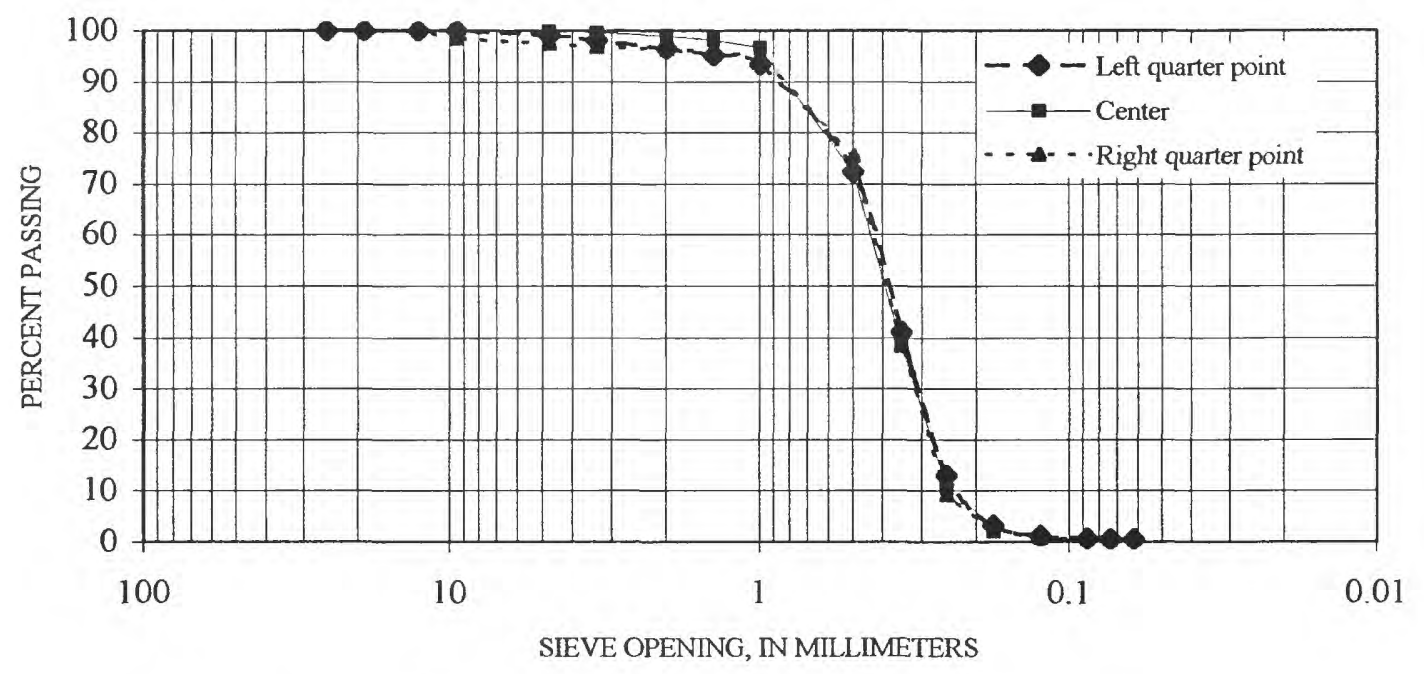

Figure 2.--Grain-size analysis of bed-material samples collected in July 1997 at Hotopha Creek near Batesville.

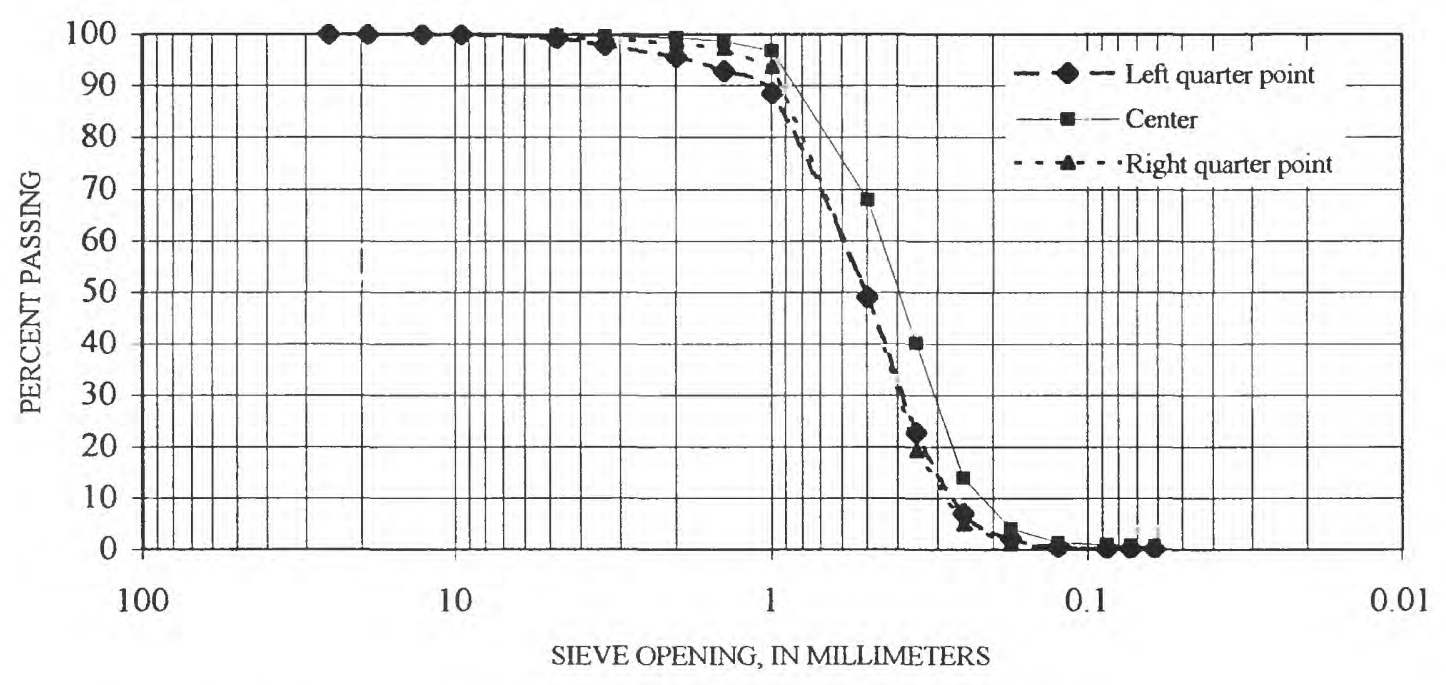

Figure 3.-- Grain-size analysis of bed-material samples collected in July 1997 at Otoucalofa Creek near Water Valley. 


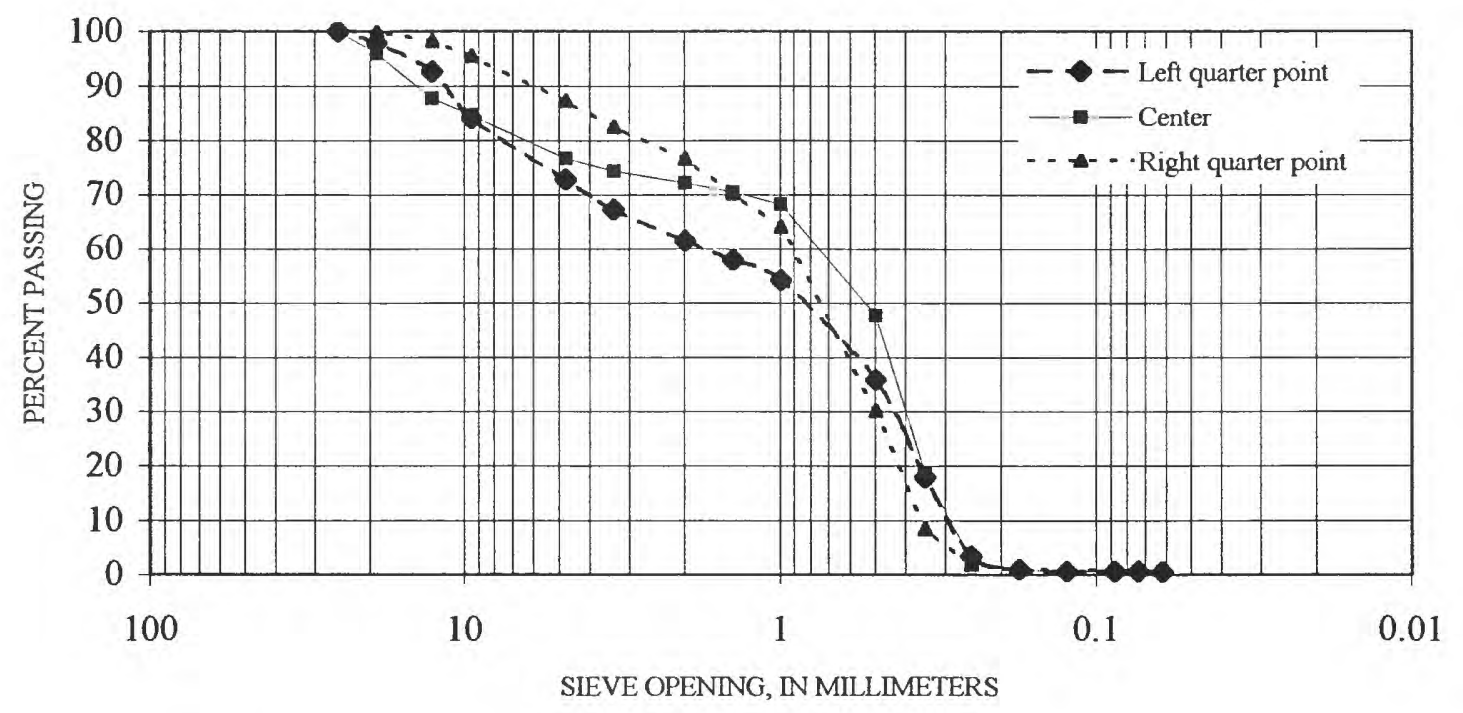

Figure 4.-- Grain-size analysis of bed-material samples collected in July 1997 at Peters Creek near Pope.

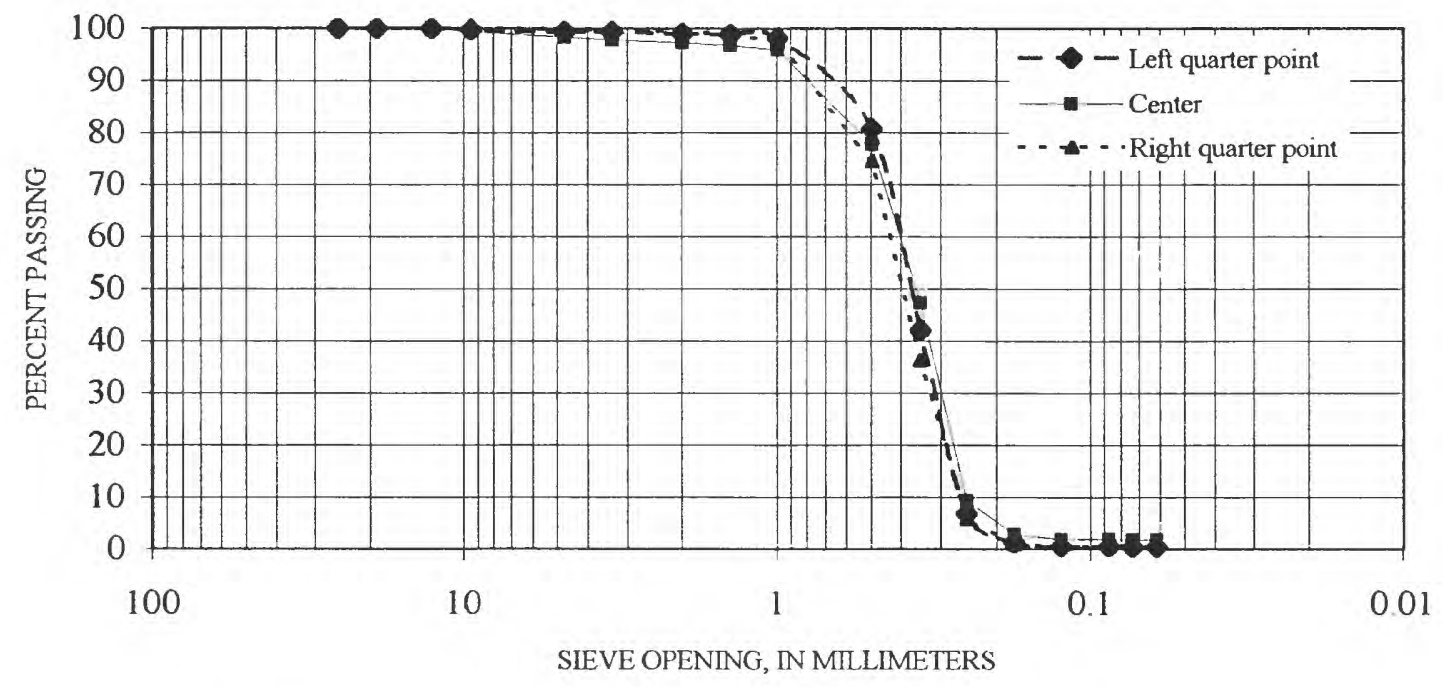

Figure 5.-- Grain-size analyses of bed-material samples collected in July 1997 at Hickahala Creek near Senatobia. 


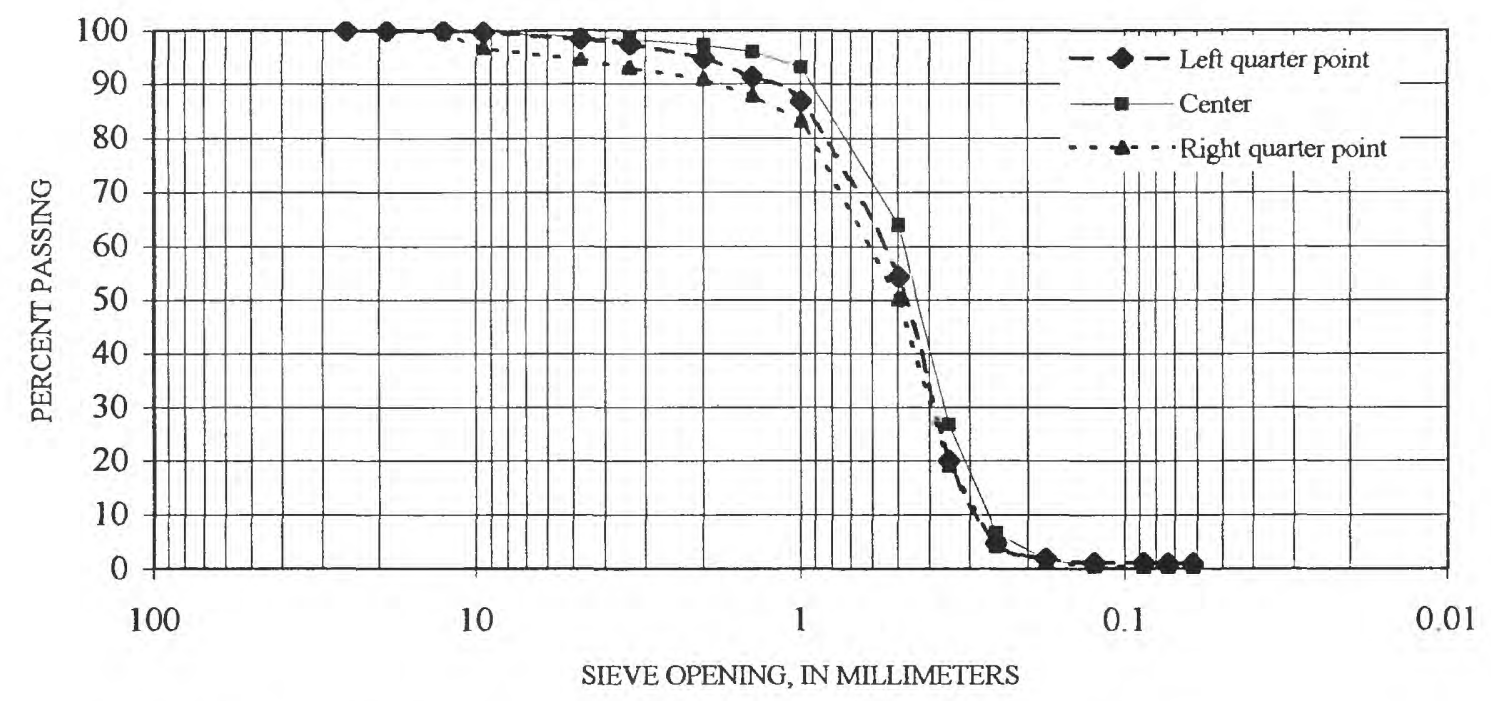

Figure 6.-- Grain-size analysis of bed-material samples collected in July 1997 at Abiaca Creek near Seven Pines.

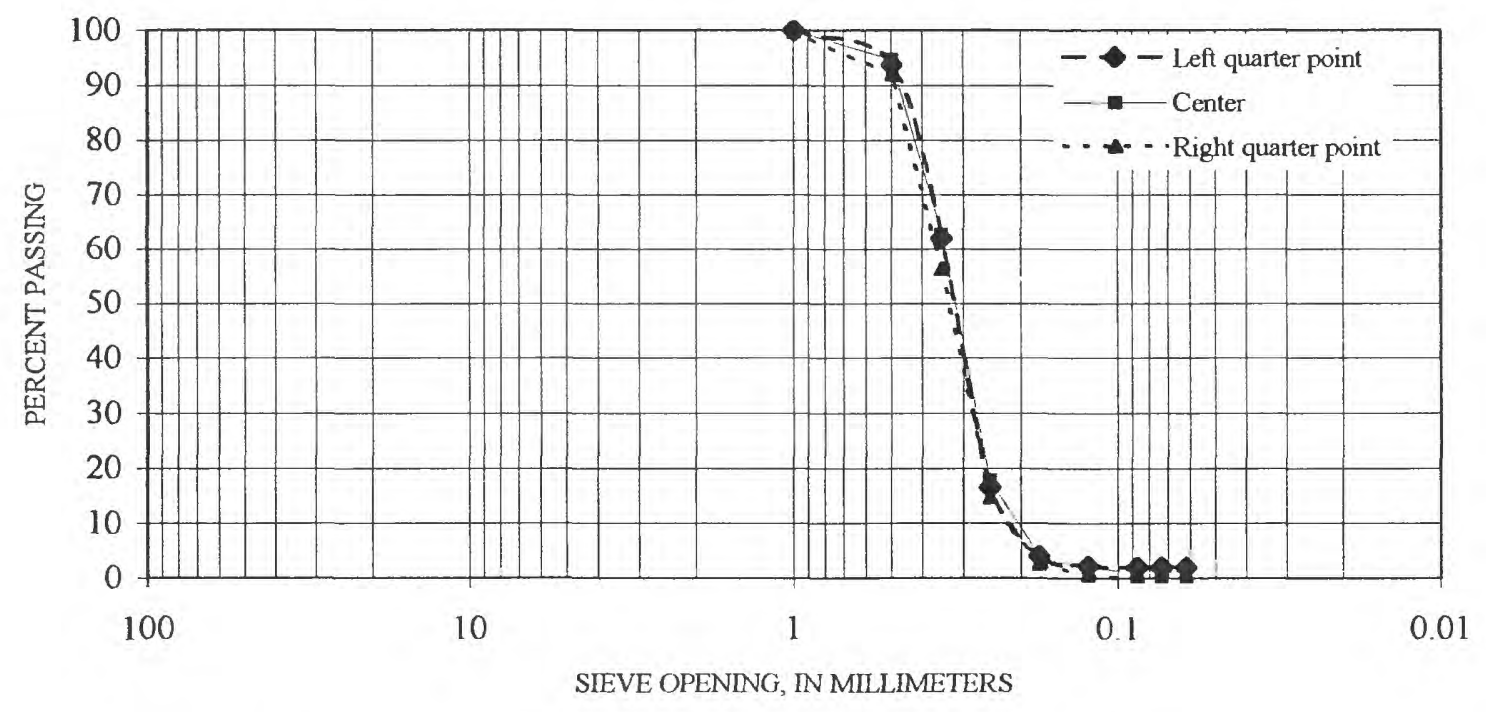

Figure 7.-- Grain-size analyses of bed-material samples collected in July 1997 at Abiaca Creek near Cruger. 


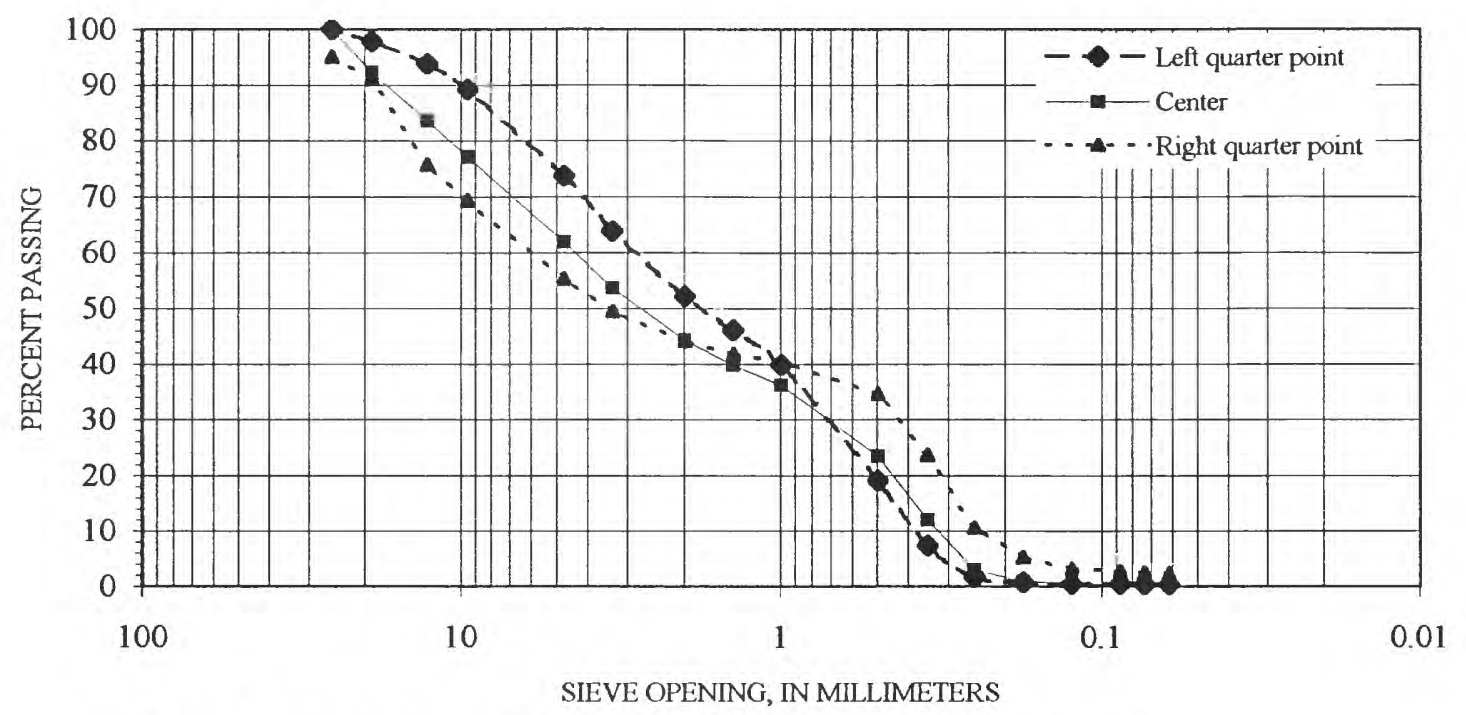

Figure 8.-- Grain-size analysis of bed-material samples collected in July 1997 at Harland Creek near Howard. 


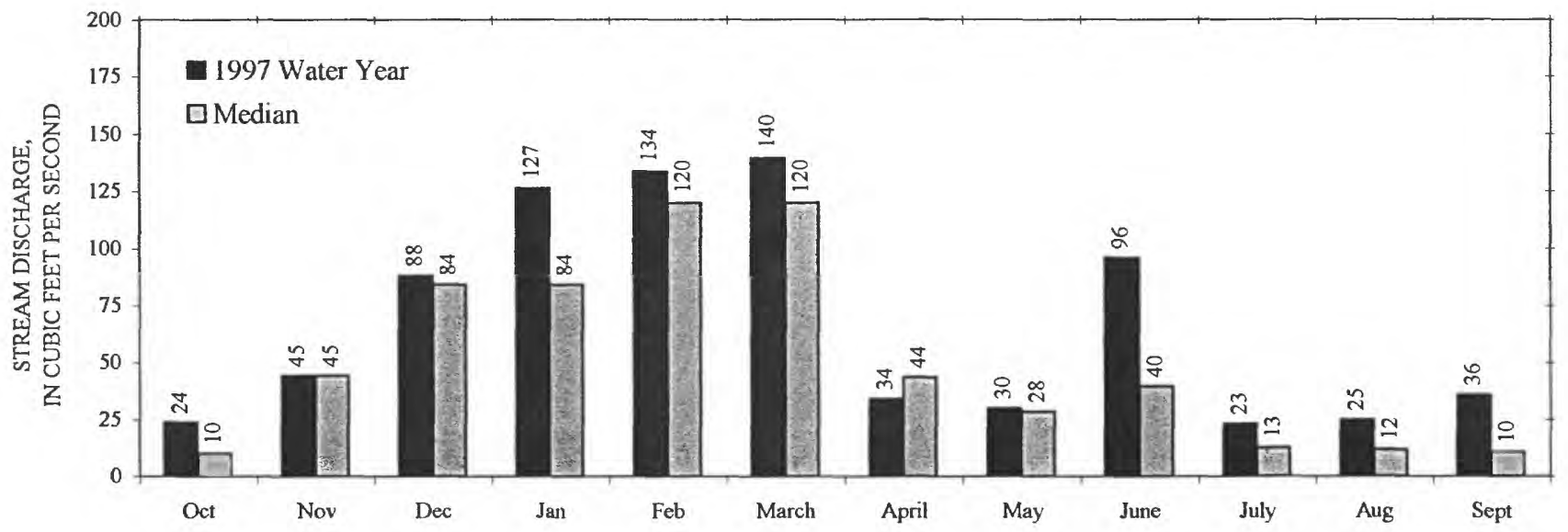

(a)

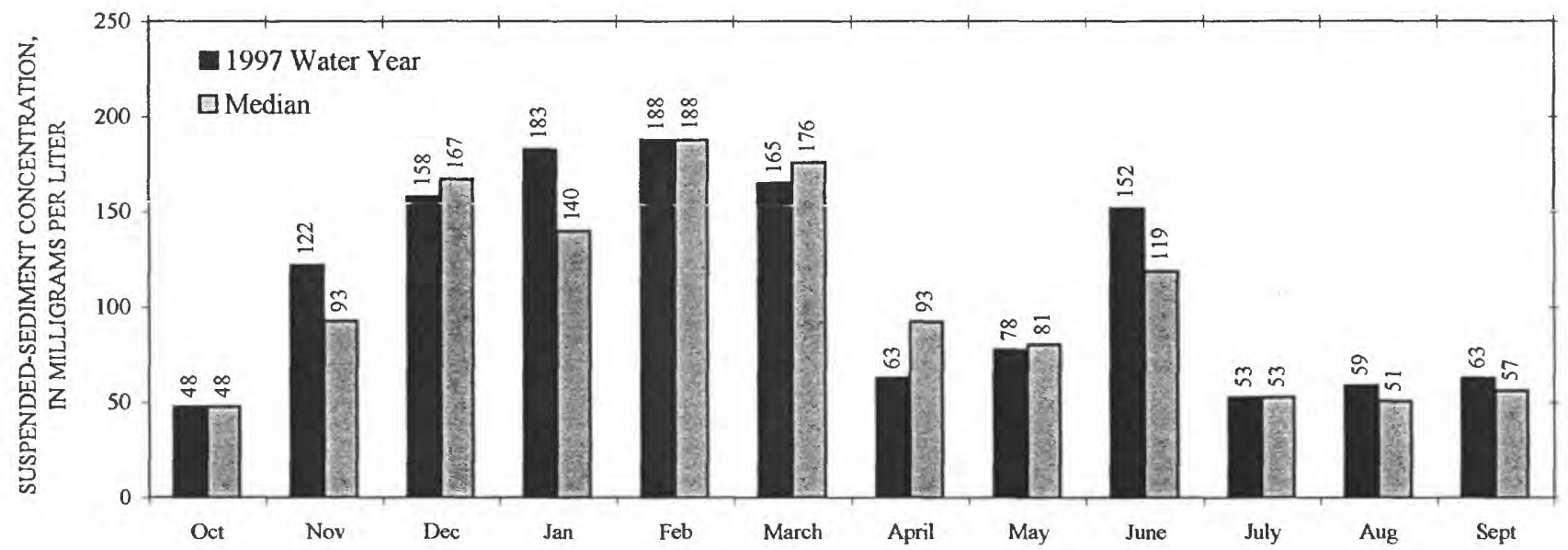

(b)

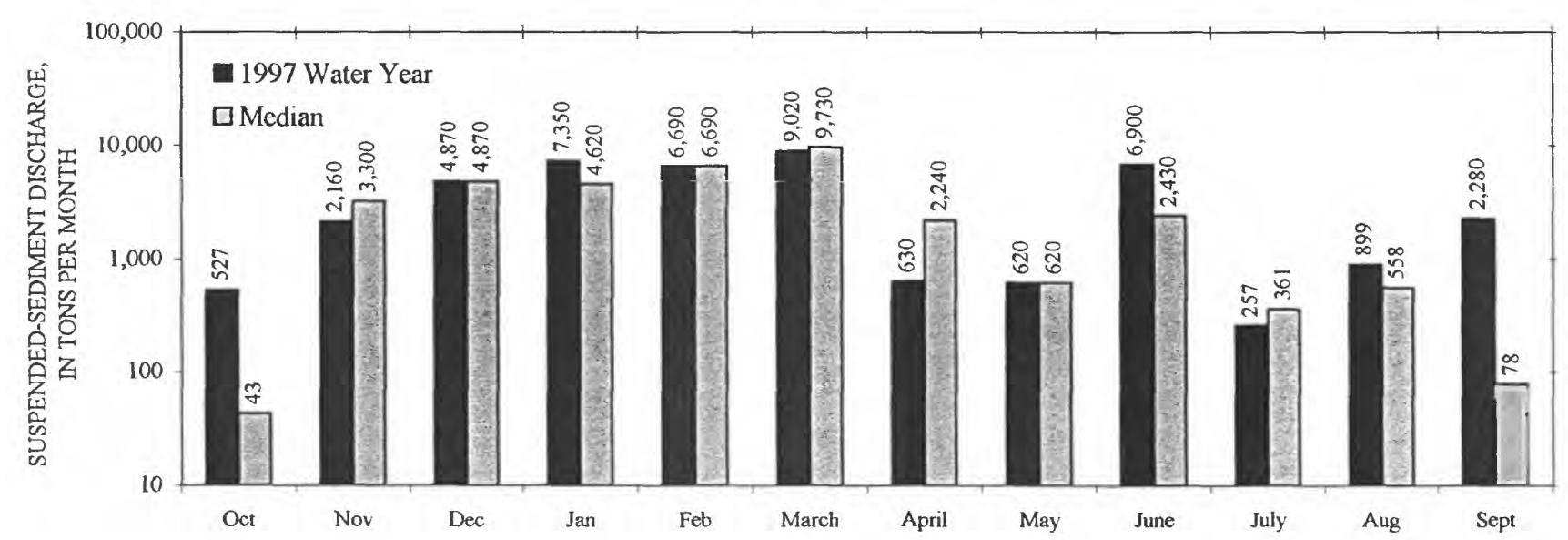

(c)

Figure 9.--Values for the 1997 water year and median values for the period of record for (a) monthly-mean stream discharge, (b) monthly-mean suspended-sediment concentration, and (c) suspended-sediment discharge for Hotopha Creek near Batesville, Mississippi. 


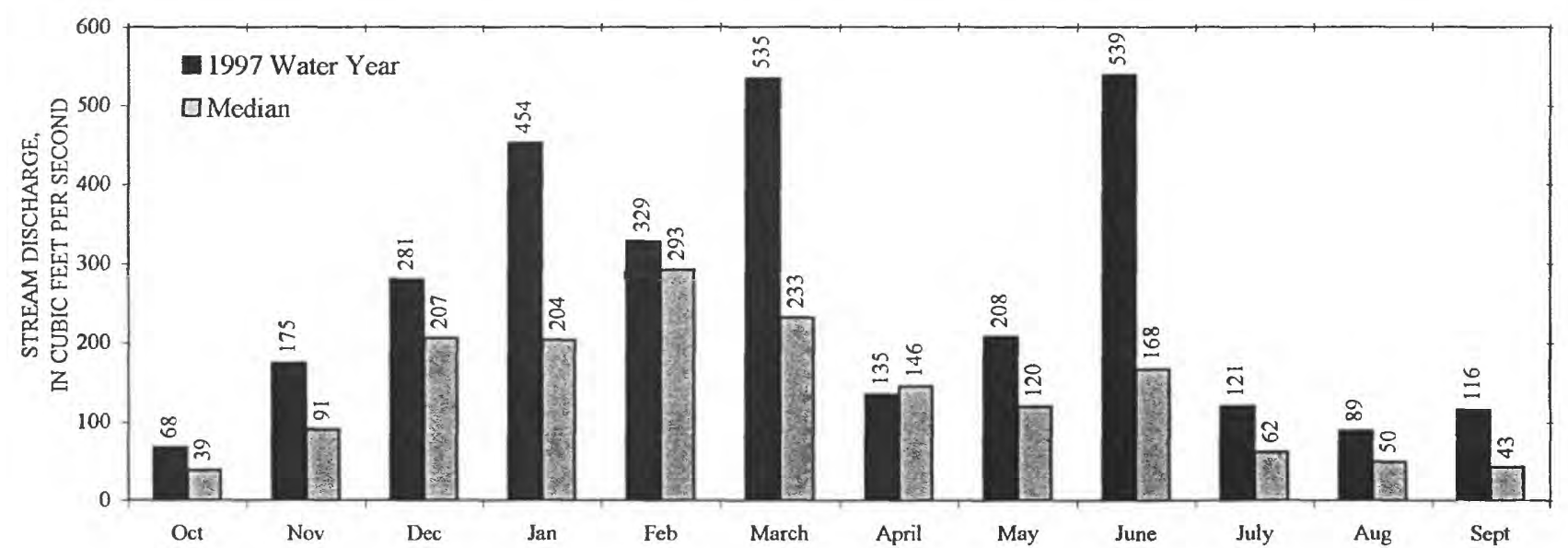

(a)

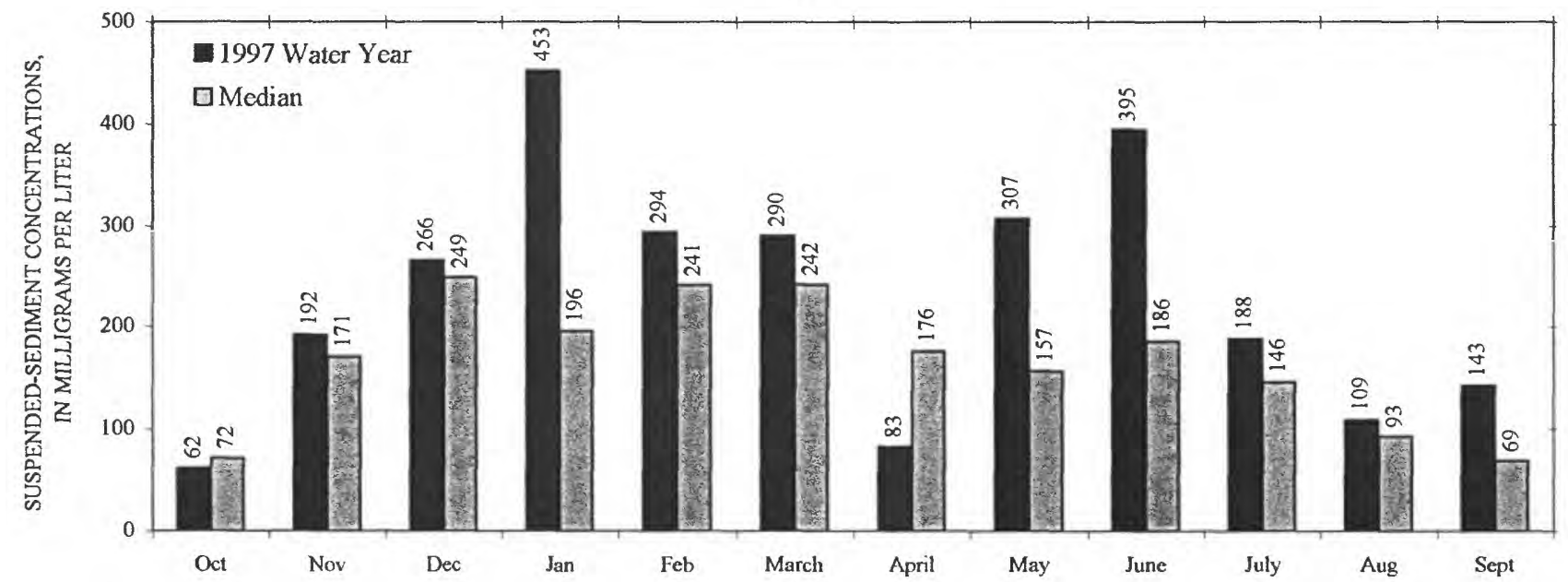

(b)

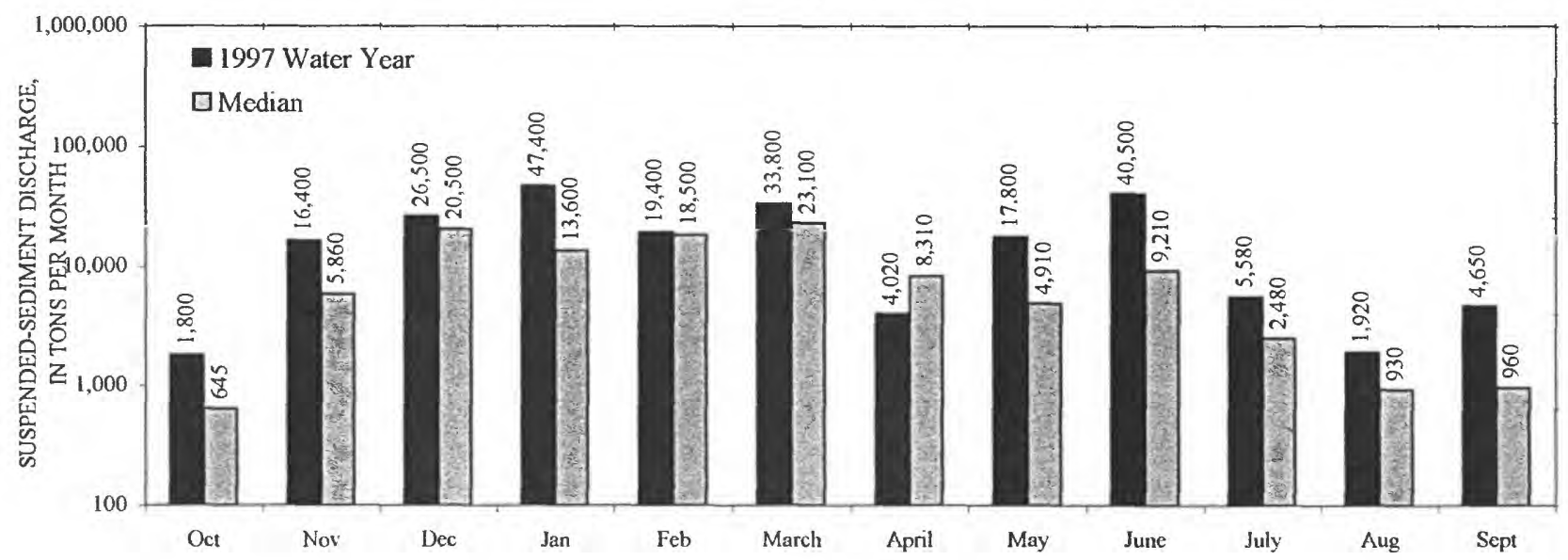

(c)

Figure 10.--Values for the 1997 water year and median values for the period of record for (a) monthly-mean stream discharge, (b) monthly-mean suspended-sediment concentration, and (c) suspended-sediment discharge for Otoucalofa Creek near Water Valley, Mississippi. 


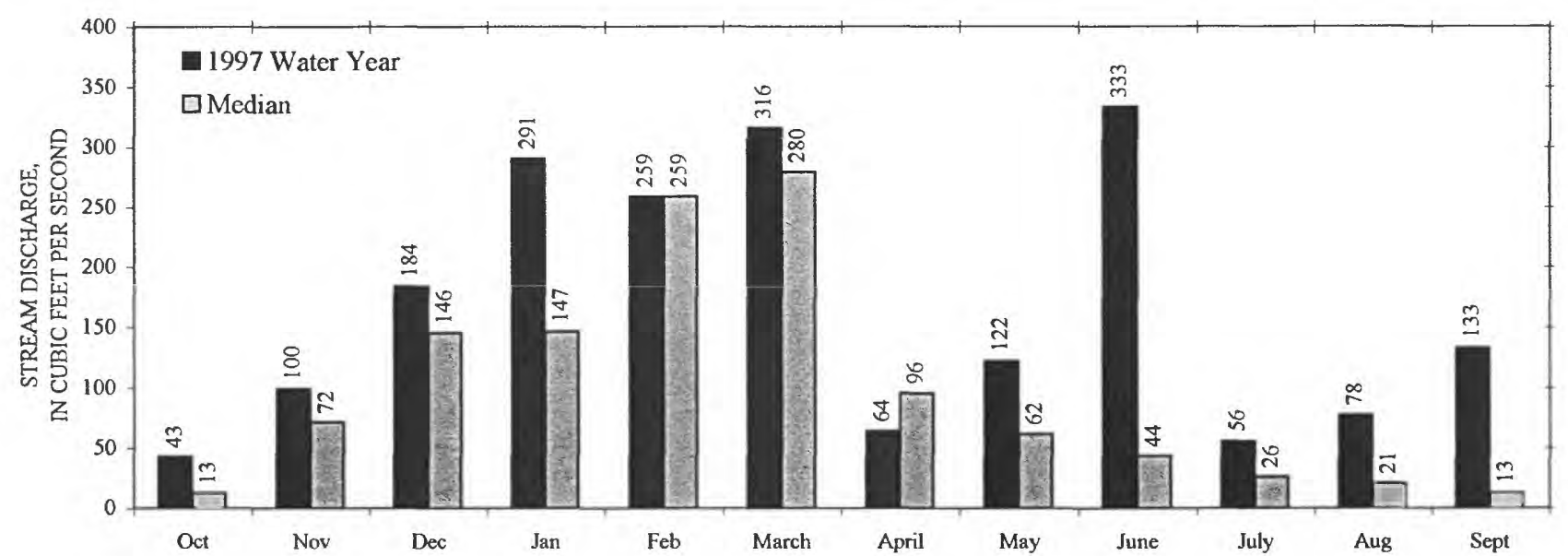

(a)

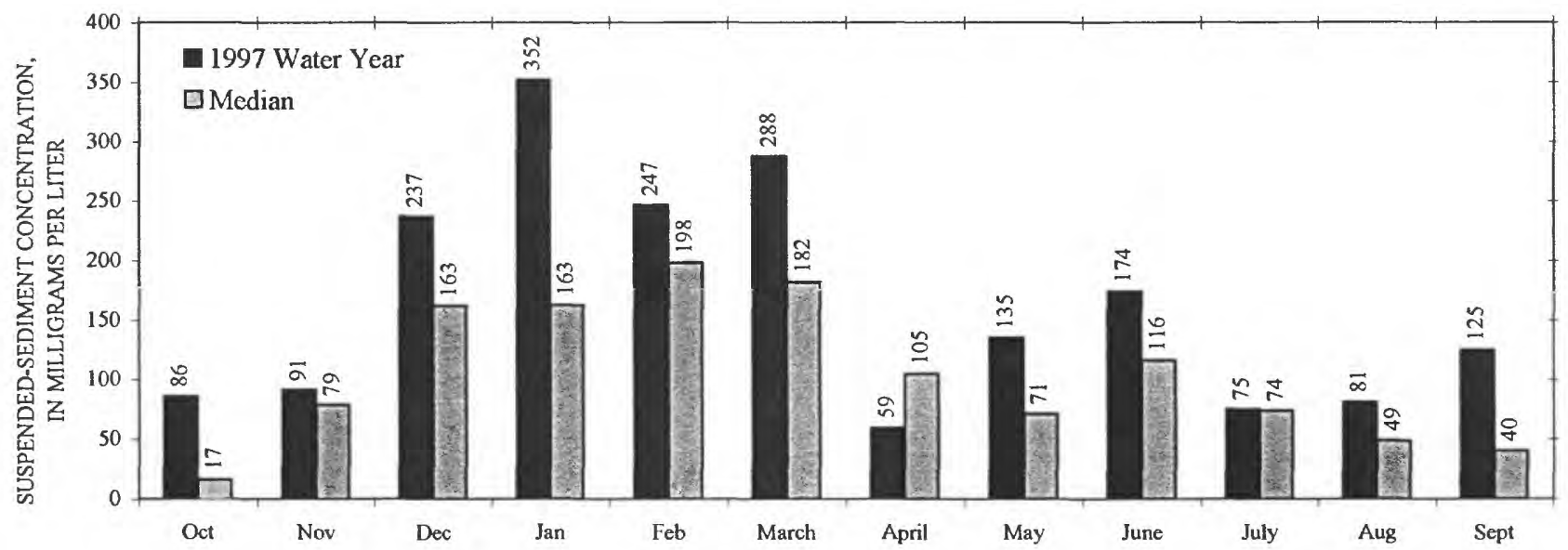

(b)

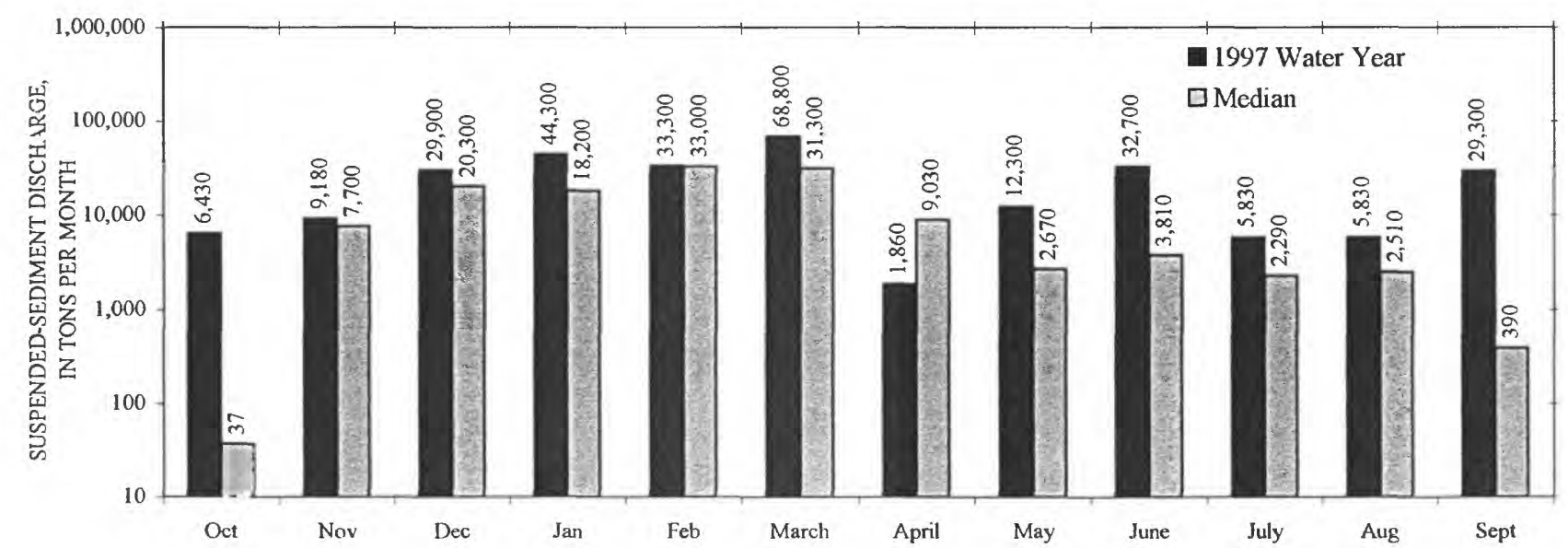

(c)

Figure 11 .--Values for the 1997 water year and median values for the period of record for (a) monthly-mean stream discharge, (b) monthly-mean suspended-sediment concentration, and (c) suspended-sediment discharge for Peters Creek near Pope, Mississippi. 


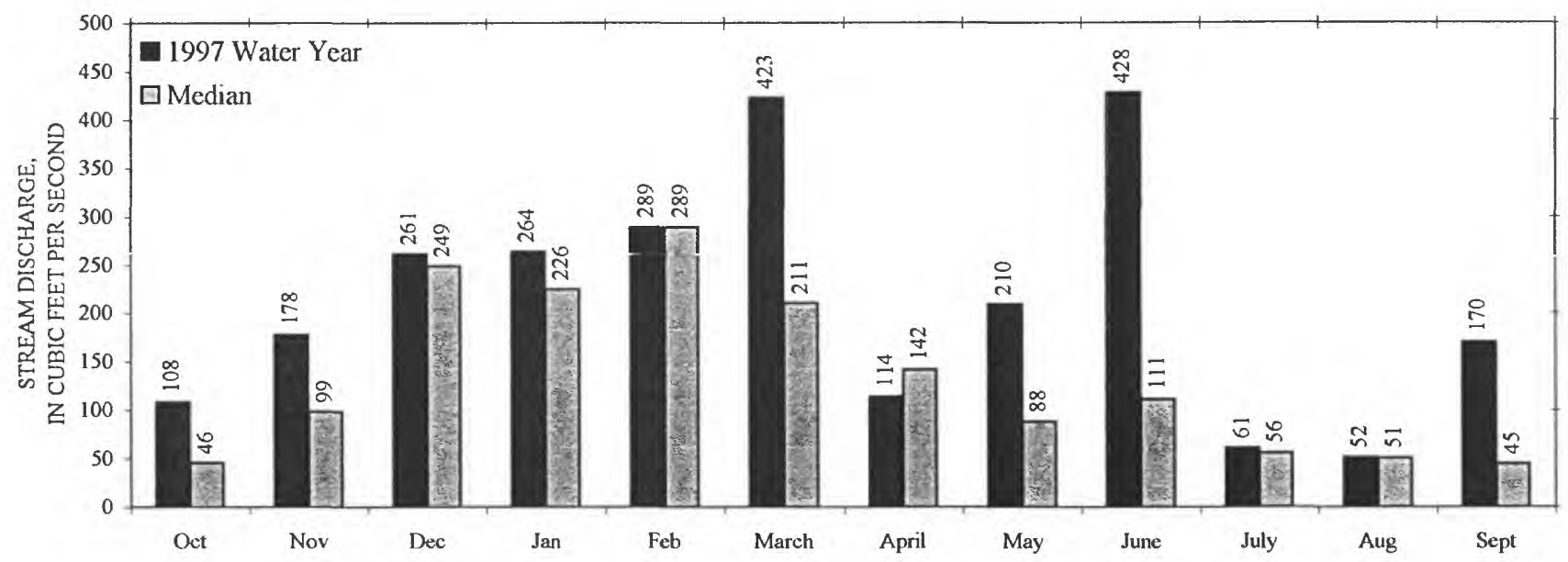

(a)

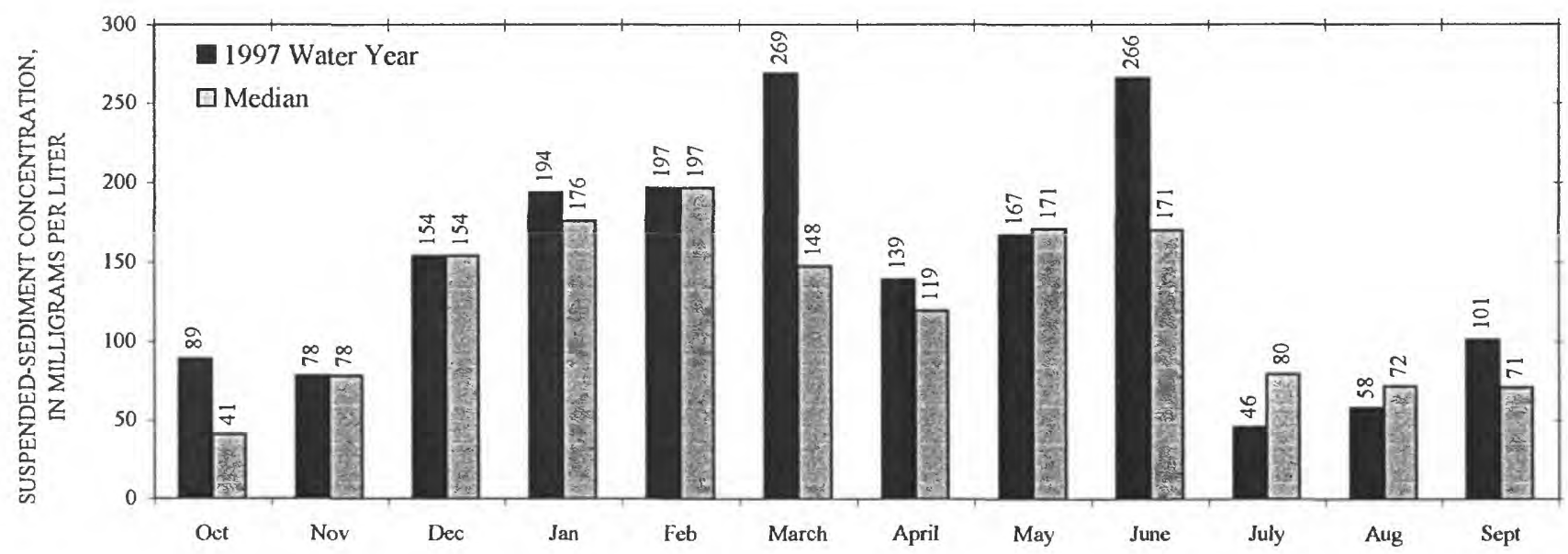

(b)

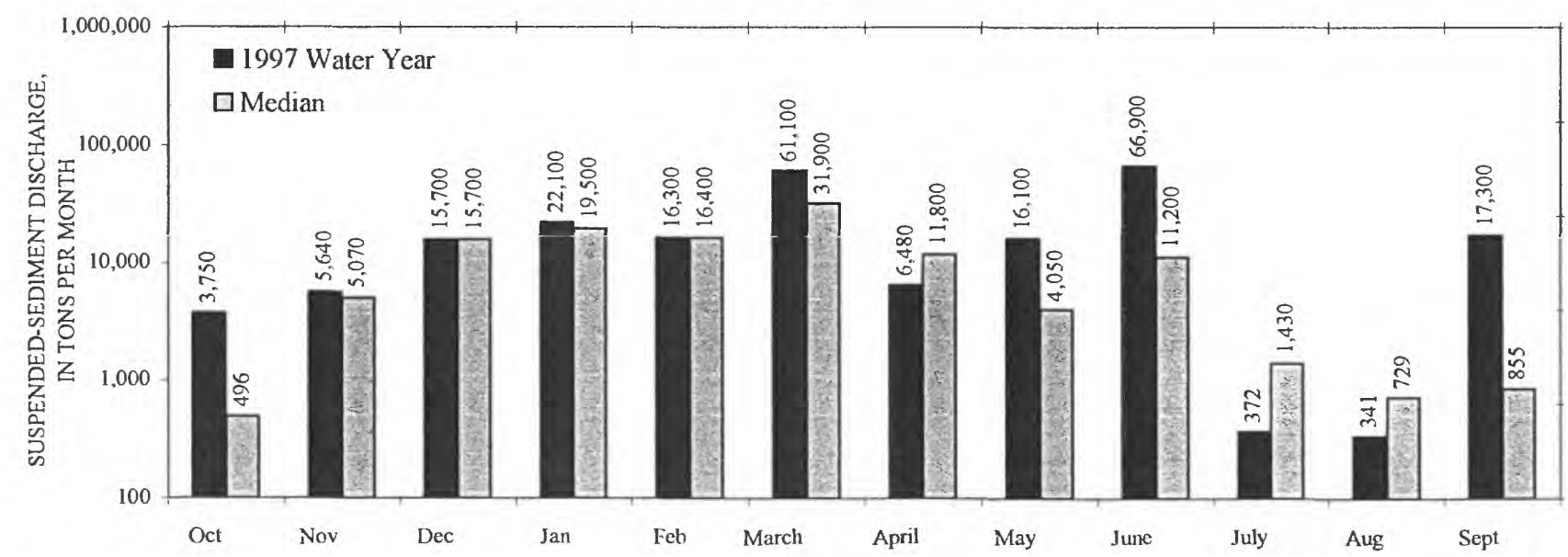

(c)

Figure 12.--Values for the 1997 water year and median values for the period of record for (a) monthly-mean stream discharge, (b) monthly-mean suspended-sediment concentration, and (c) suspended-sediment discharge for Hickahala Creek near Senatobia, Mississippi. 


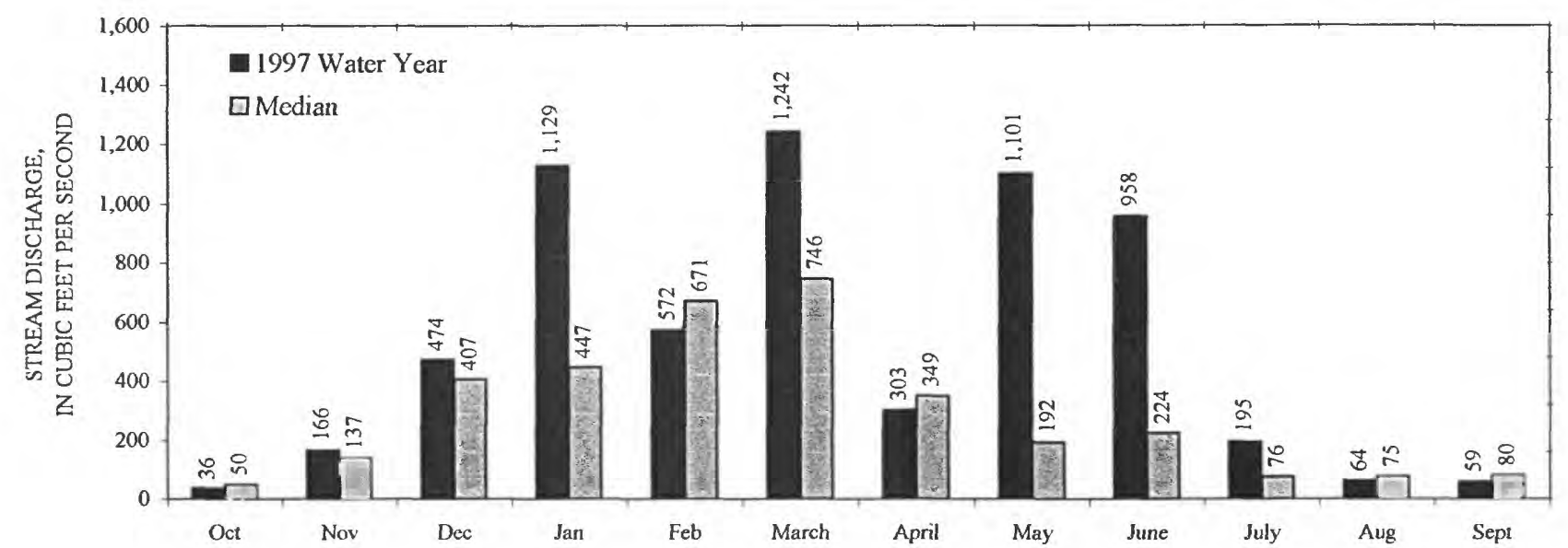

(a)

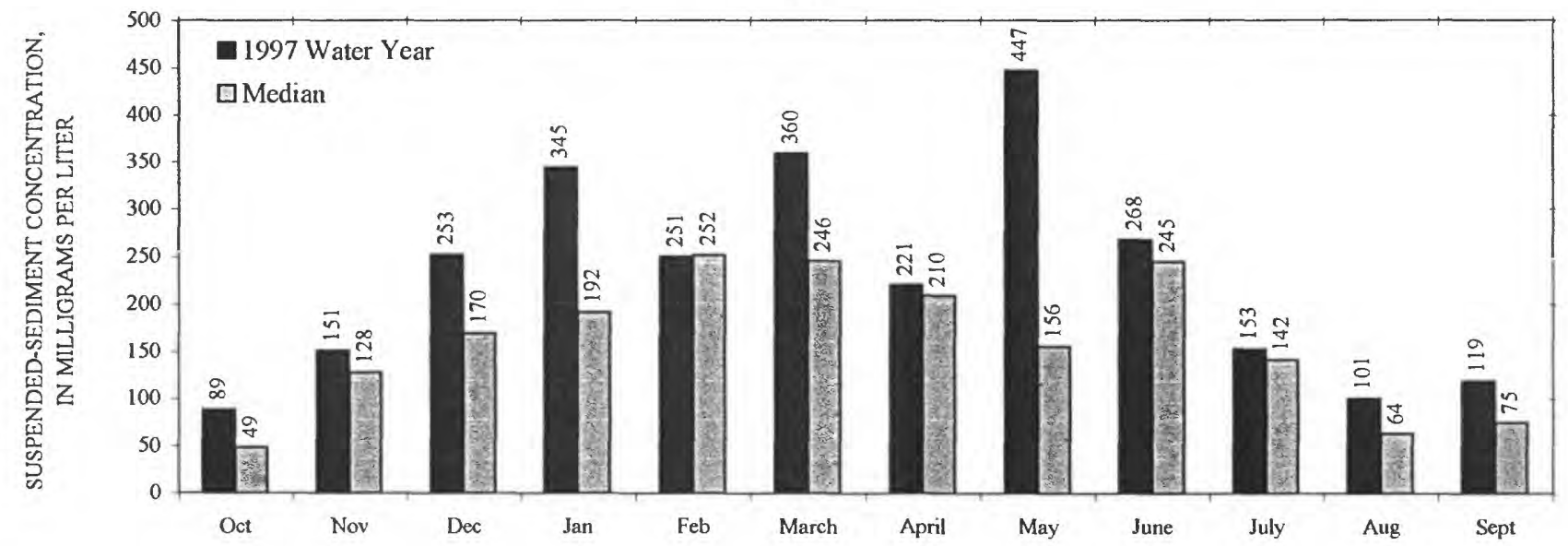

(b)

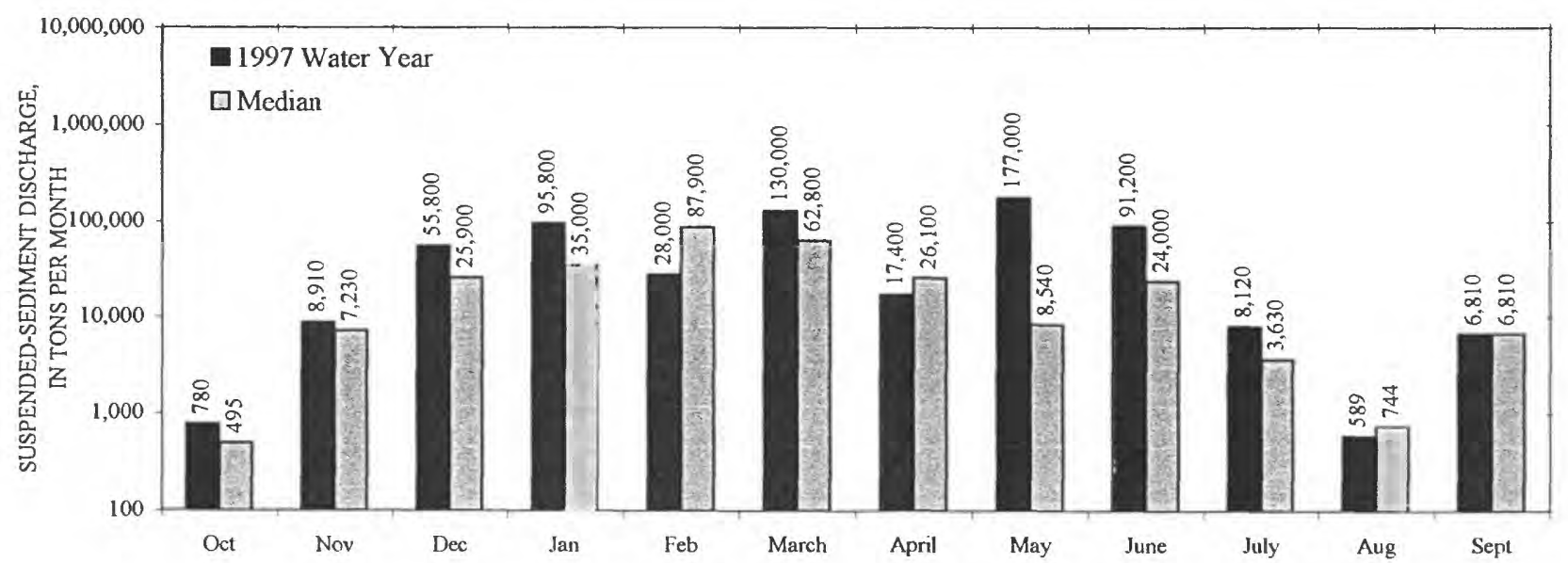

(c)

Figure 13.--Values for the 1997 water year and median values for the period of record for (a) monthly-mean stream discharge, (b) monthly-mean suspended-sediment concentration, and (c) suspended-sediment discharge for Batupan Bogue at Grenada, Mississippi. 


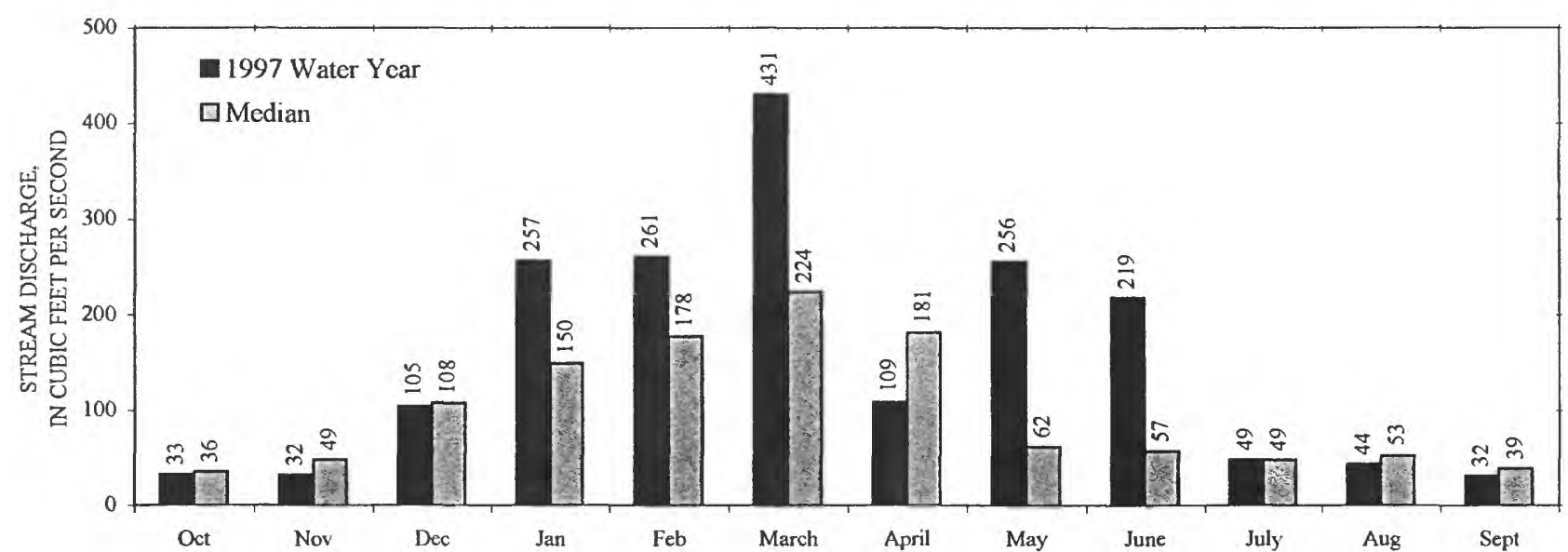

(a)

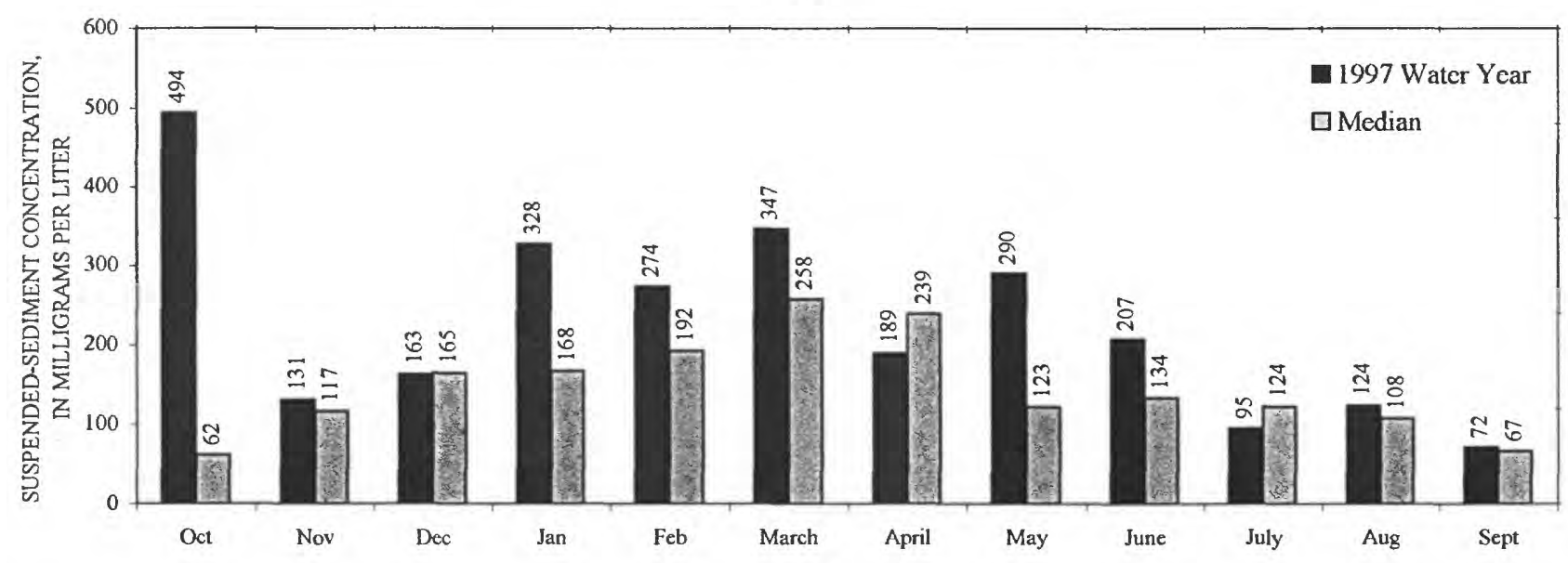

(b)

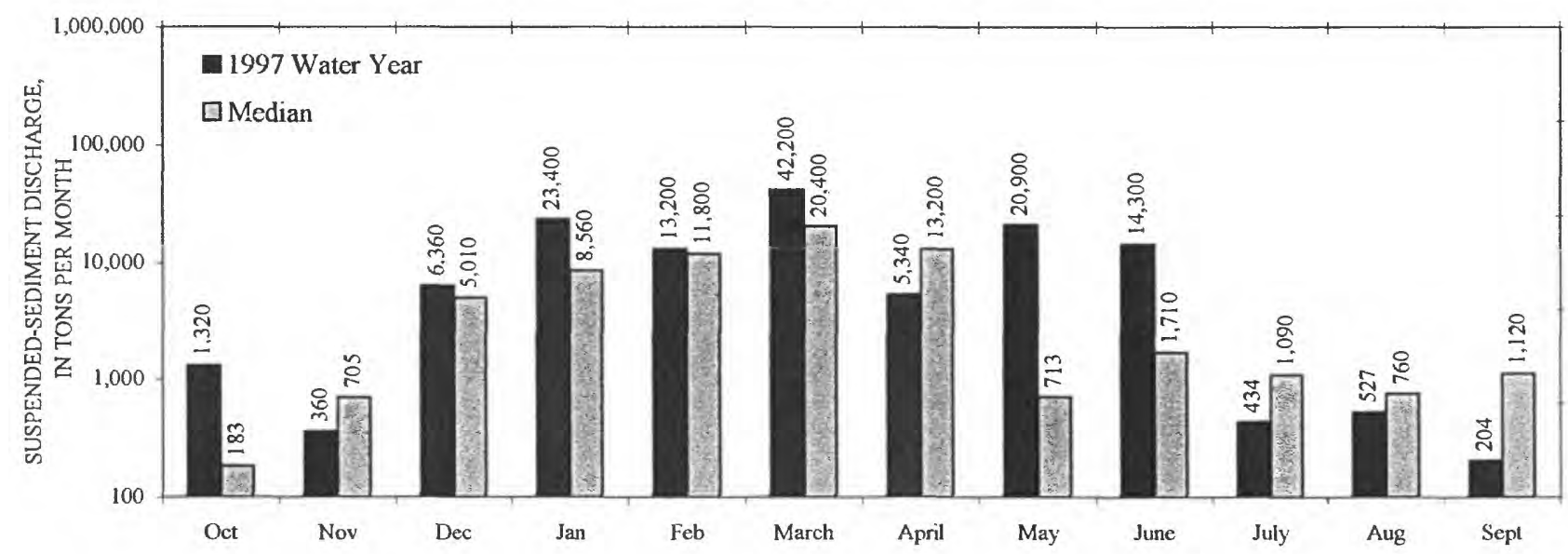

(c)

Figure 14.--Values for the 1997 water year and median values for the period of record for (a) monthly-mean stream discharge, (b) monthly-mean suspended-sediment concentration, and (c) suspended-sediment discharge for Abiaca Creek near Seven Pines, Mississippi. 


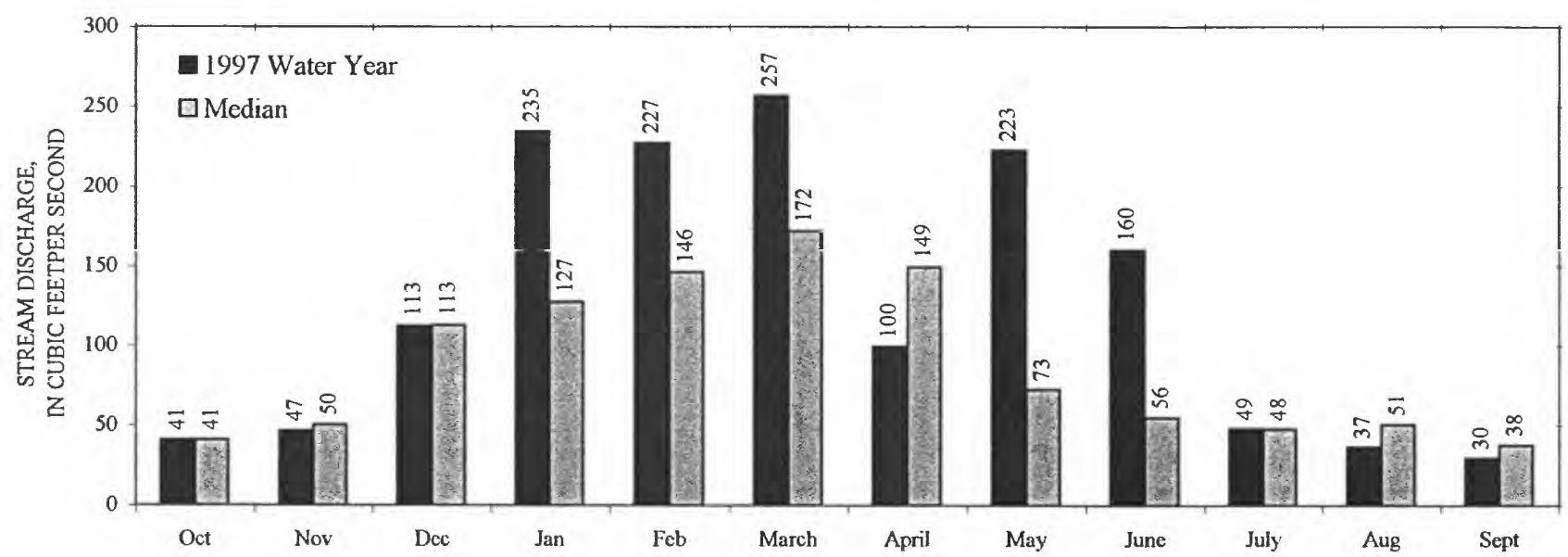

(a)

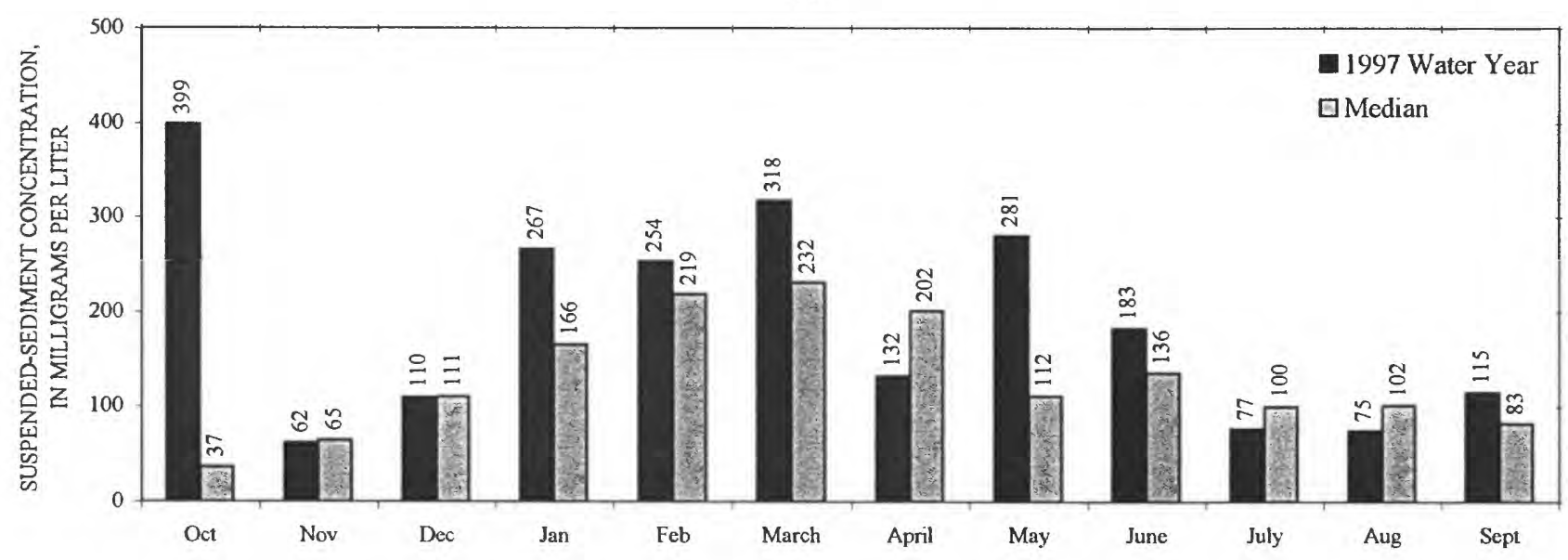

(b)

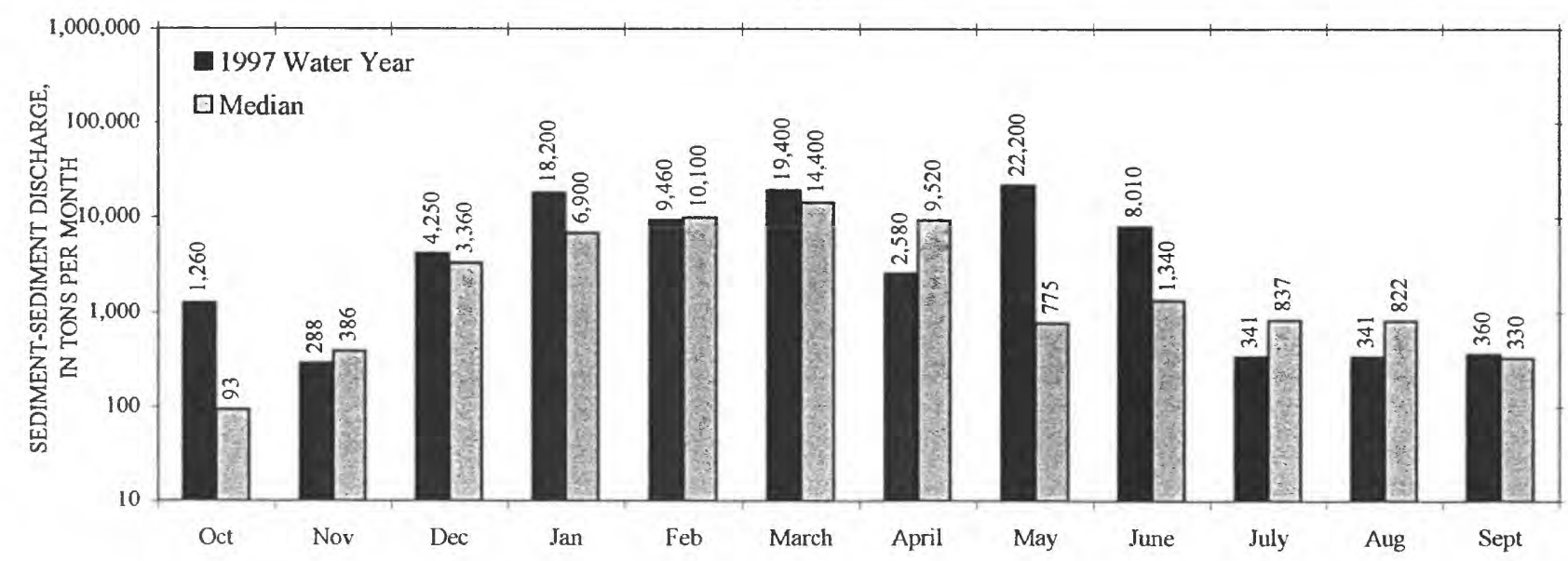

(c)

Figure 15.--Values for the 1997 water year and median values for the period of record for (a) monthly-mean stream discharge, (b) monthly-mean suspended-sediment concentration, and (c) suspended-sediment discharge for Abiaca Creek near Cruger, Mississippi. 


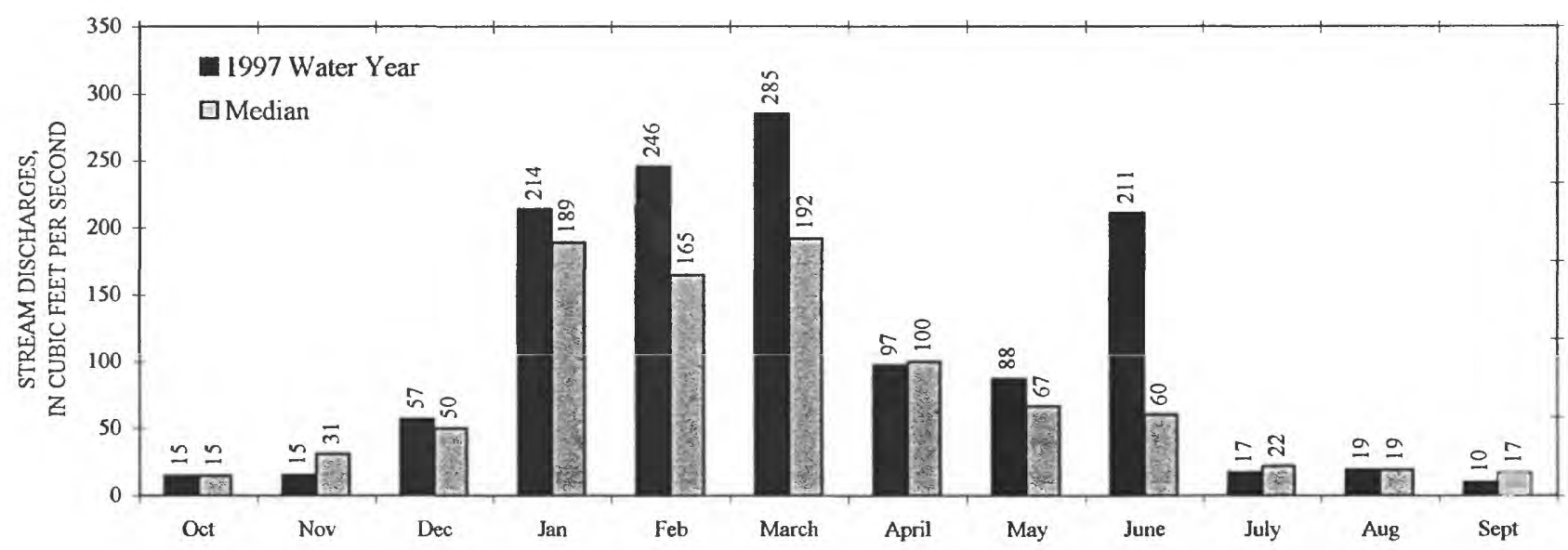

(a)

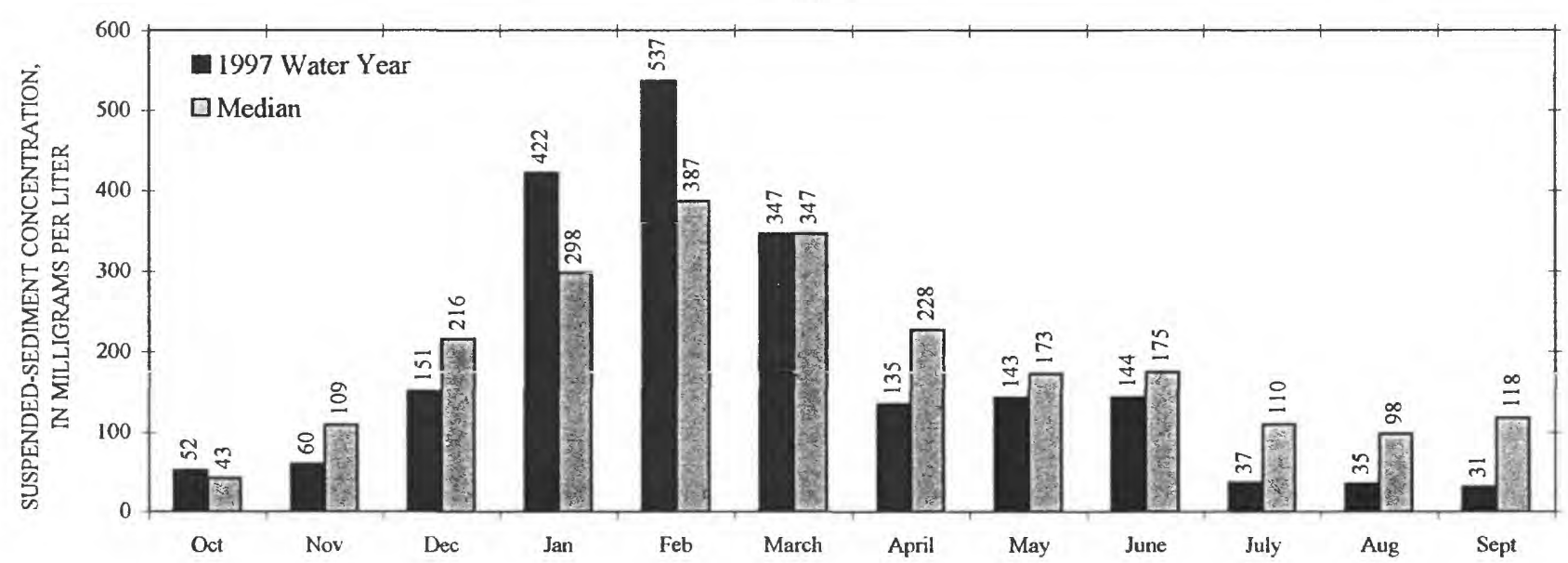

(b)

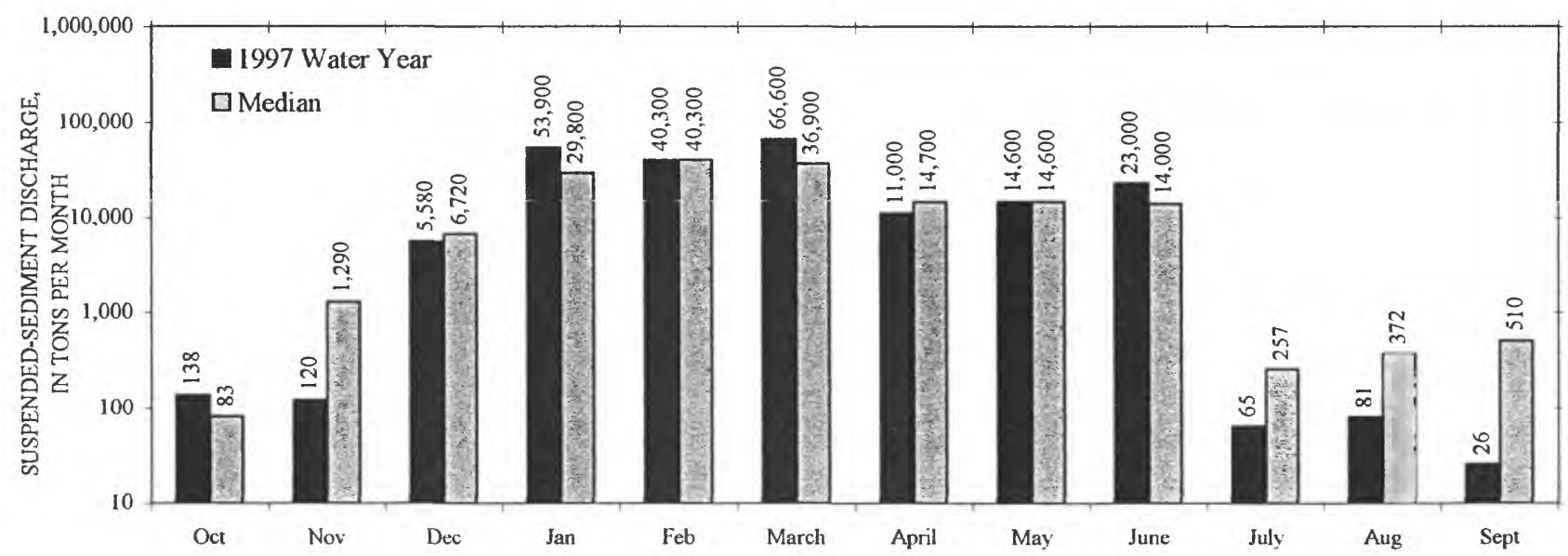

(c)

Figure 16.--Values for the 1997 water year and median values for the period of record for (a) monthly-mean stream discharge, (b) monthly-mean suspended-sediment concentration, and (c) suspended-sediment discharge for Harland Creek near Howard, Mississippi. 


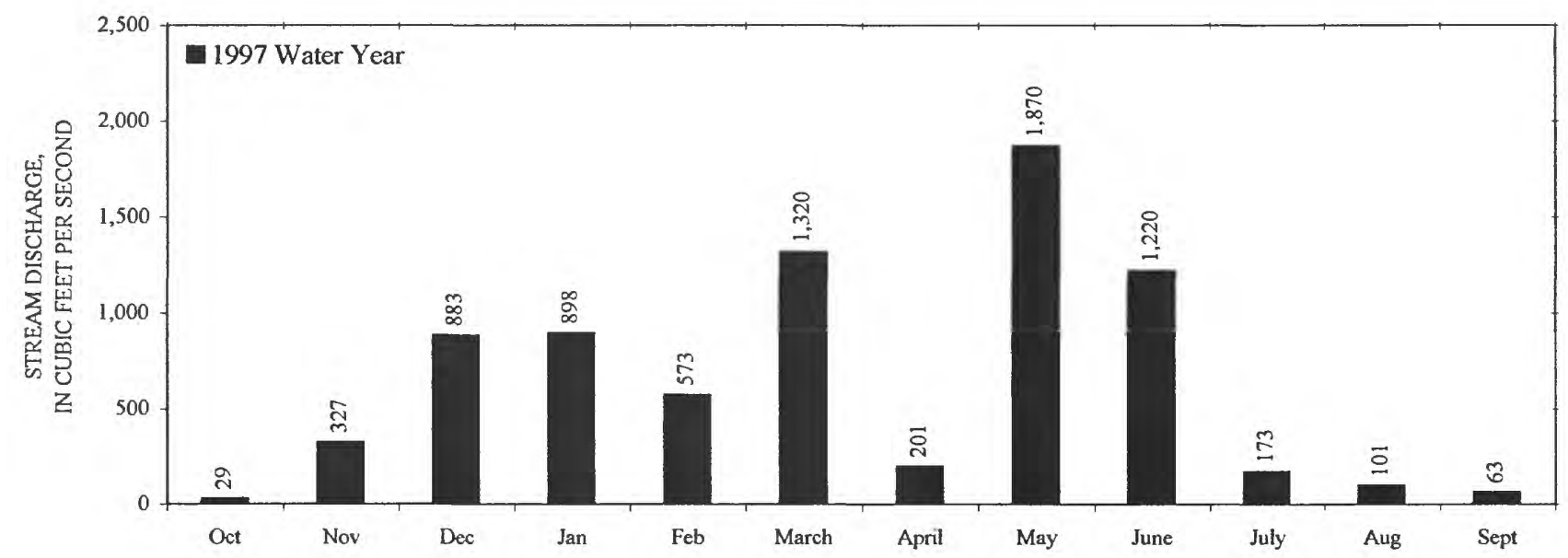

(a)

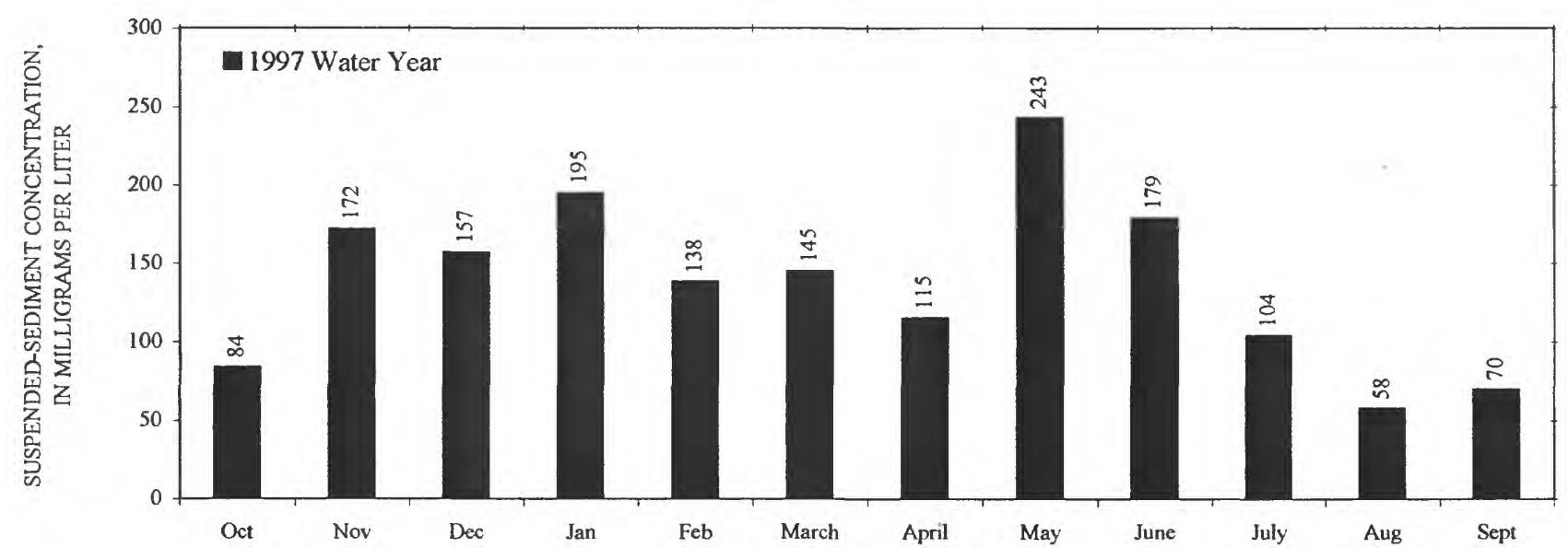

(b)

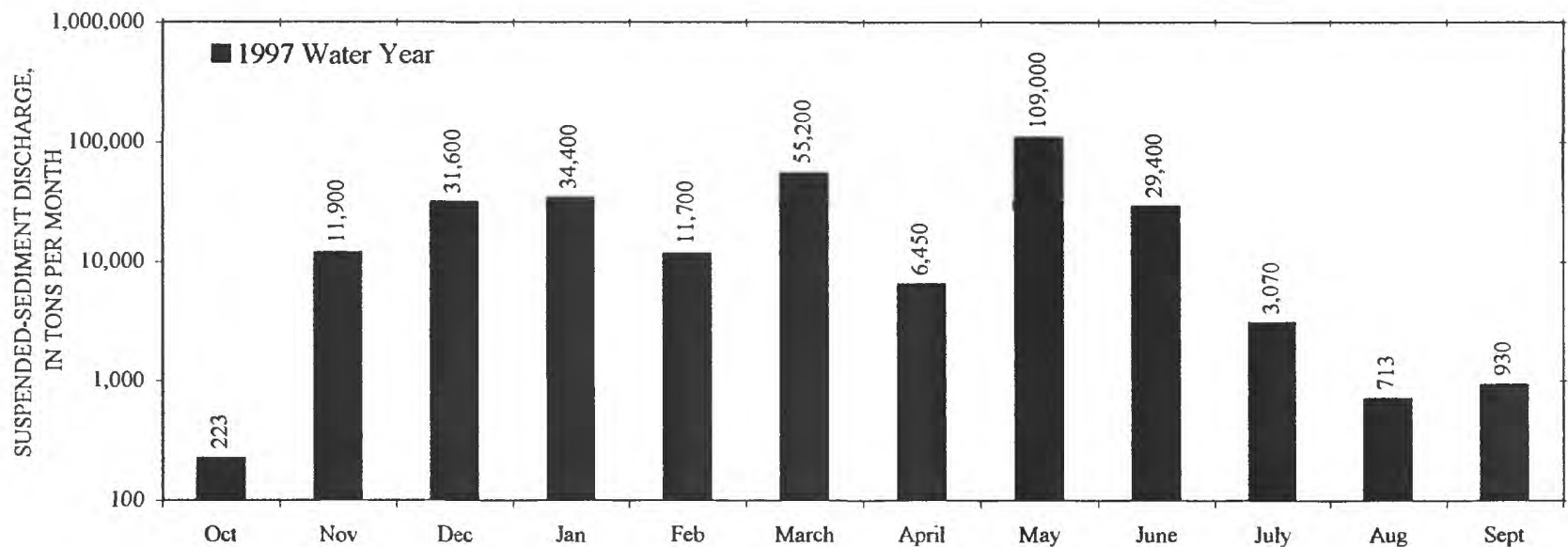

(c)

Figure 17.--Values for the 1997 water year for (a) monthly-mean stream discharge, (b) monthly-mean suspended-sediment concentration, and (c) suspended-sediment discharge for Yalobusha River near Calhoun City, Mississippi. 


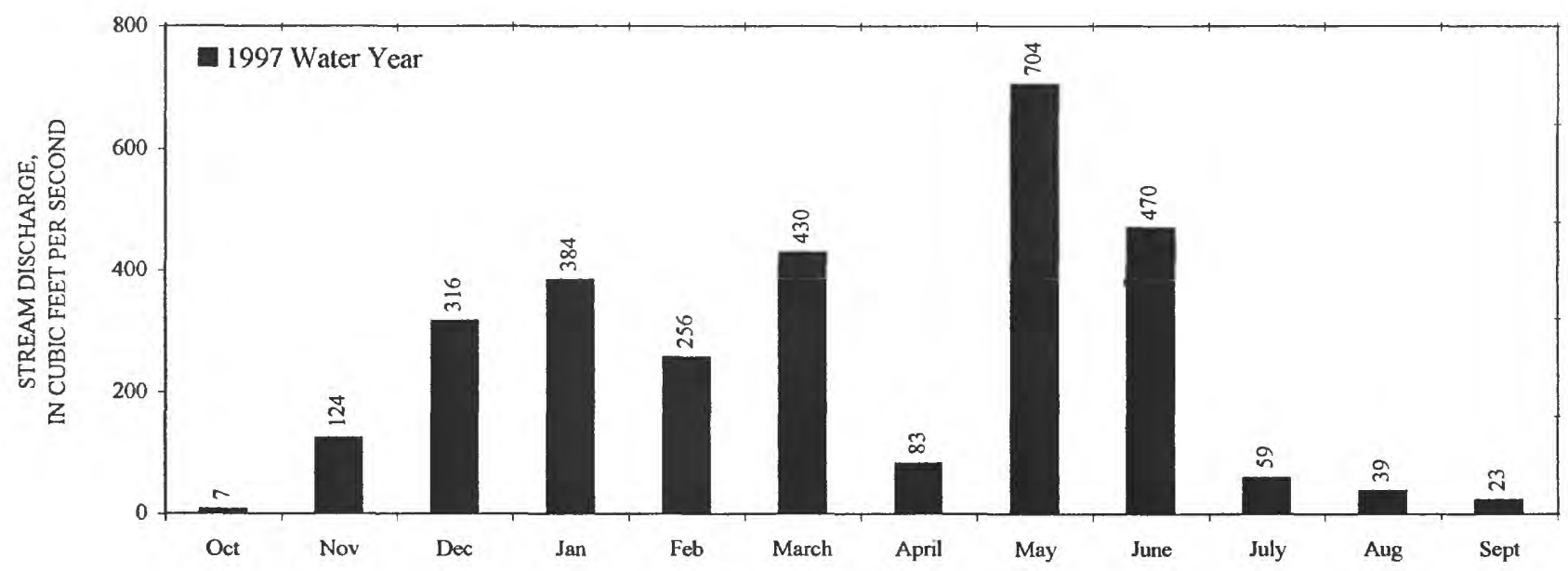

(a)

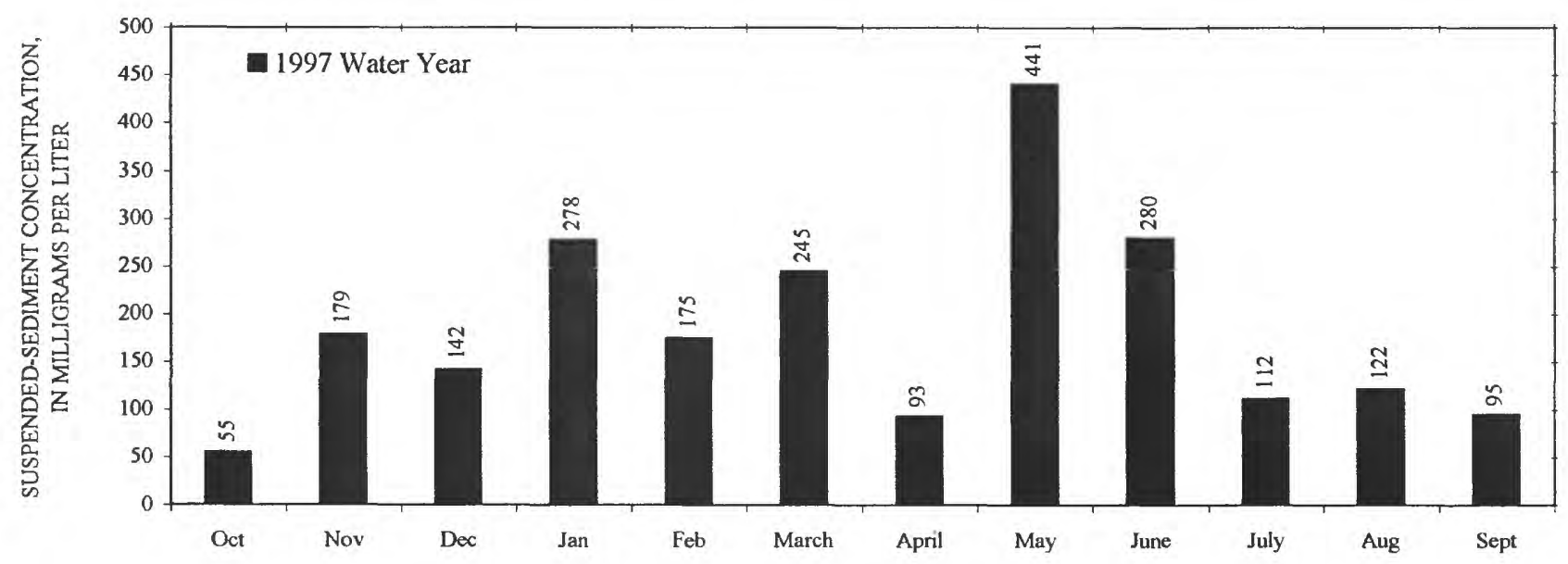

(b)

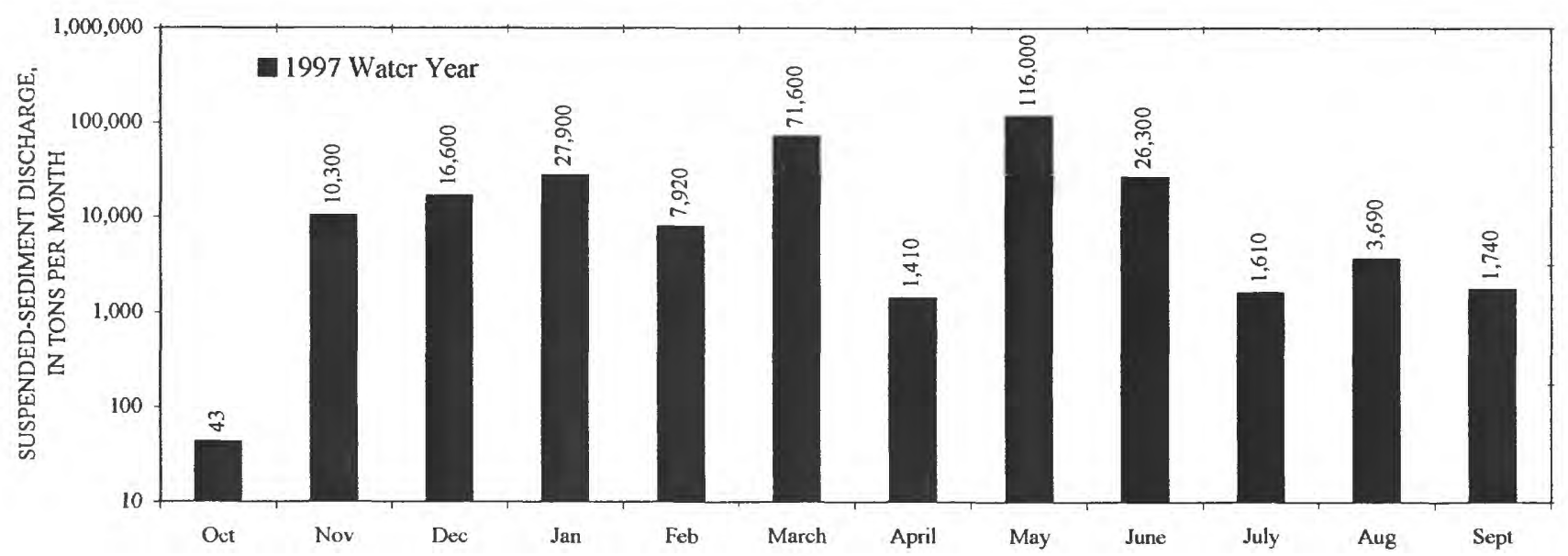

(c)

Figure 18.--Values for the 1997 water year for (a) monthly-mean stream discharge, (b) monthly-mean suspended-sediment concentration, and (c) suspended-sediment discharge for Topashaw Creek near Calhoun City, Mississippi. 